\section{To: (Receiving Organization) \\ Distribution}

5. Proj./Prog./Dept./Div.:

Readiness To Proceed/TFC

8. Originator Remarks:

N/A

\begin{tabular}{l} 
\\
\hline $\begin{array}{l}\text { 11. Receiver Remarks: } \\
\text { N/A }\end{array}$
\end{tabular}

\begin{tabular}{l} 
\\
\hline $\begin{array}{l}\text { 11. Receiver Remarks: } \\
\text { N/A }\end{array}$
\end{tabular}

3. From: (Originating Organization)
Readiness to Proceed
$\begin{aligned} & \text { 6. Design Authority/Design Agent/Cog. Engr.: } \\ & \text { J. O Honeyman }\end{aligned}$

3. From: (Originating Organization)

6. Design Authority/Design Agent/Cog. Engr.:

J. O Honeyman

11A. Design Baseline Document? $\square$ Yes $\bigotimes$ No
4. Related EDT No.:
N/A
7. Purchase Order No.:
$\mathrm{N} / \mathrm{A}$
9. Equip./Component No.:
$\mathrm{N} / \mathrm{A}$
10. System/Bldg./Facility:
$\mathrm{N} / \mathrm{A}$
12. Major Assm. Dwg. No.:
$\mathrm{N} / \mathrm{A}$

13. Permit/Permit Application No.:

$\mathrm{N} / \mathrm{A}$

14. Required Response Date:

$\mathrm{N} / \mathrm{A}$

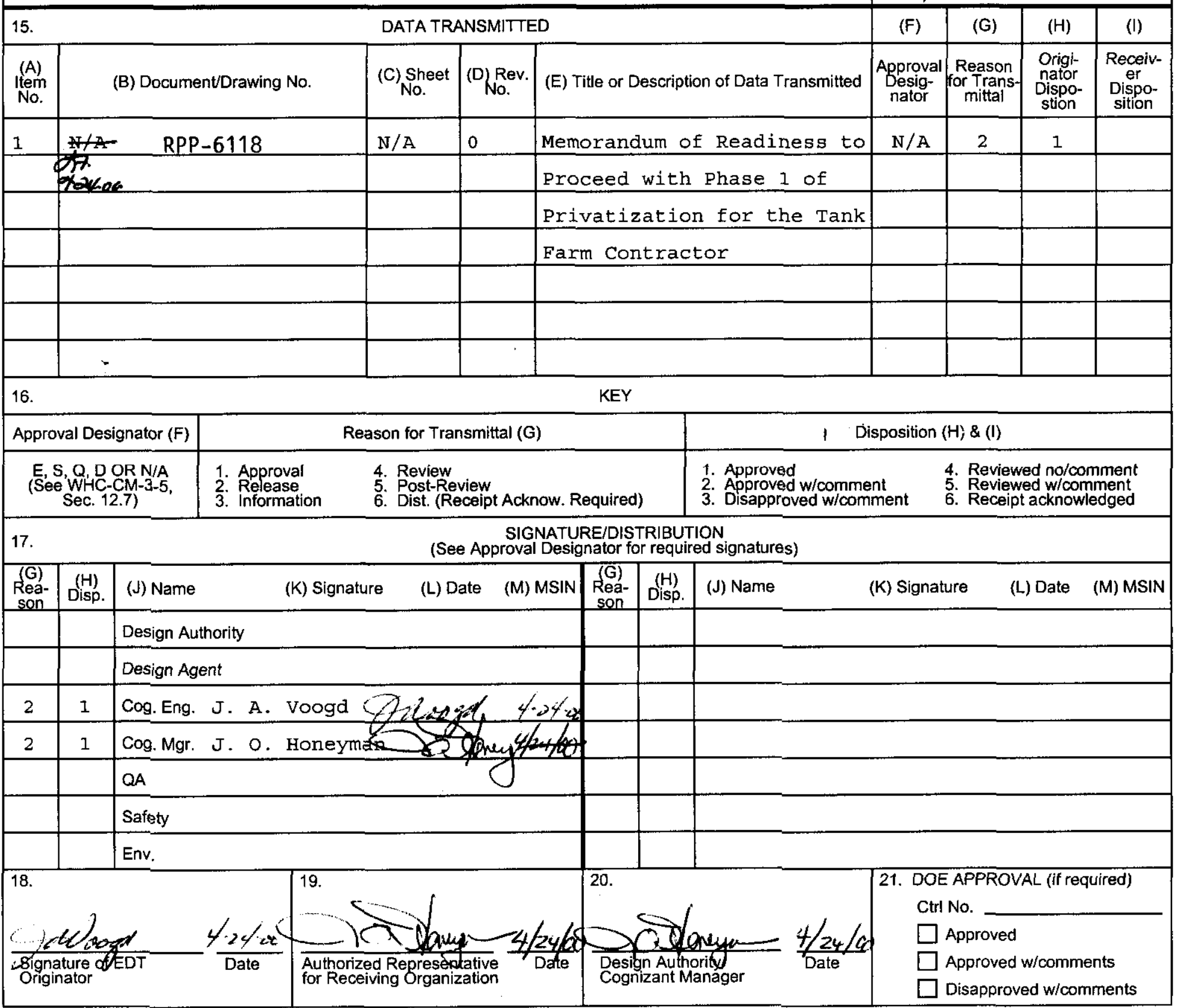


RPP-6118

Revision 0

\section{Memorandum of Readiness to Proceed with Phase 1 Privatization for the Tank Farm Contractor}

Prepared for the U.S. Department of Energy Assistant Secretary for Environmental Management

\section{CH2MHILL Hanford Group, Inc.}

Richland, Washington

Contractor for the U.S. Department of Energy

Office of River Protection under Contract DE-ACO6-99RL14047

Approved for Public Release; Further Dissemination Unlimited 
LEGAL DISCLAIMER

This report was prepared as an account of work sponsored by an agency of the United States Government. Neither the United States Government nor any agency thereof, nor any of their employees, nor any of their contractors, subcontractors or their employees, makes any warranty, express or implied, or assumes any legal liability or responsibility for the accuracy, completeness, or any third party's use or the results of such use of any information, apparatus, product, or process disclosed, or represents that its use would not infringe privately owned rights. Reference herein to any specific commercial product, process, or service by trade name, trademark, manufacturer, or otherwise, does not necessarily constitute or imply its endorsement,

recommendation, or favoring by the United States Government or any agency thereof or its contractors or subcontractors. The views and opinions of authors expressed herein do not necessarily state or reflect those of the United States Government or any agency thereof.

This report has been reproduced from the best available copy.

Available in paper copy and microfiche.

Available electronically at http://www.doe.gov/bridge. Available for a processing fee to the U.S. Department of Energy and its contractors, in paper, from:

U.S. Department of Energy Office of Scientific and Technical Information P.O. Box 62

Oak Ridge, TN $37831-0062$

phone: $865-576-8401$

fax: 865-576-5728

email: reports@adonis.osti.gov(423) 576-8401

Available for sale to the public, in paper, from:

U.S. Department of Commerce

National Technical Information Service

5285 Port Royal Road

Springfield, VA 22161

Phone: 800-553-6847

fax: 703-605-6900

email: orders@ntis.fedworld.gov

online ordering:

http://www.ntis.gov/ordering.htm 


\title{
Memorandum of Readiness To Proceed with Phase 1 Privatization for the Tank Farm Contractor
}

\author{
J.O. Honeyman and J.A. Voogd \\ CH2M HILL Hanford Group, Inc. \\ Richland, WA 99352 \\ U.S. Department of Energy Contract DE-AC06-99RL14047

$\begin{array}{lll}\text { EDT/ECN: } & 629528 & \text { UC: } 2030 \\ \text { Cost Center: } 71300 & \text { Charge Code: } 108512 / \text { AA30 } \\ \text { B\&R Code: } & \text { EW3130010 } & \text { Total Pages: } 88\end{array}$

Key Words: River Protection Project, Retrieval and Disposal Mission, Readiness to Proceed

Abstract: This Readiness to Proceed Memorandum provides the CH2M HILI Hanford Group, Inc. formal certification of readiness to proceed with provision of the waste feed and infrastructure to handle the products from the privatization contractor's waste processing plant. Summary information is included from the integrated scope-cost-schedule baseline, the analyses of the baseline, management systems, and systems reviews.

TRADEMARK DISCLAIMER. Reference herein to any specific commercial product, process, or service by trade name, trademark, manufacturer, or otherwise, does not necessarily constitute or imply its endorsement, recommendation, or favoring by the United States Government or any agency thereof or its contractors or subcontractors.

Printed in the United States of America. To obtain copies of this document, contact: Document Control Services, P.O. Box 950, Mailstop H6-08, Richland WA 99352, Phone (509) 372-2420; Fax (509) 376-4989.

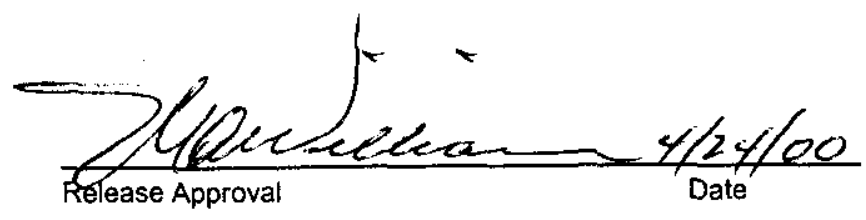

Approved For Public Release

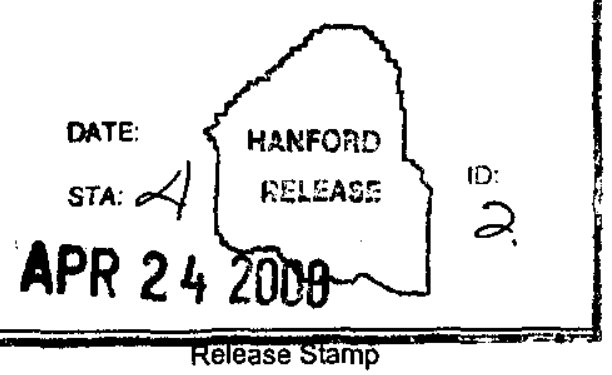


RPP-6118

Revision 0

\section{Memorandum of Readiness to Proceed with Phase 1 Privatization for the Tank Farm Contractor}

Prepared by:

J. A. Voogd

J. O. Honeyman

Date Published

April 2000

Prepared for the U.S. Department of Energy

Assistant Secretary for Environmental Management

\section{CH2MHILL \\ Hanford Group, Inc.}

P. O. Box 1500

Richland, Washington

Contractor for the U.S. Department of Energy

Office of River Protection under Contract DE-AC06-99RL14047

Approved for Public Release; Further Dissemination Unlimited 
RPP-6118 REV 0

This page intentionally left blank. 
Document Title: Memorandum of Readiness to Proceed with Phase 1 Privatization for the Tank Farm Contractor

Approved by:
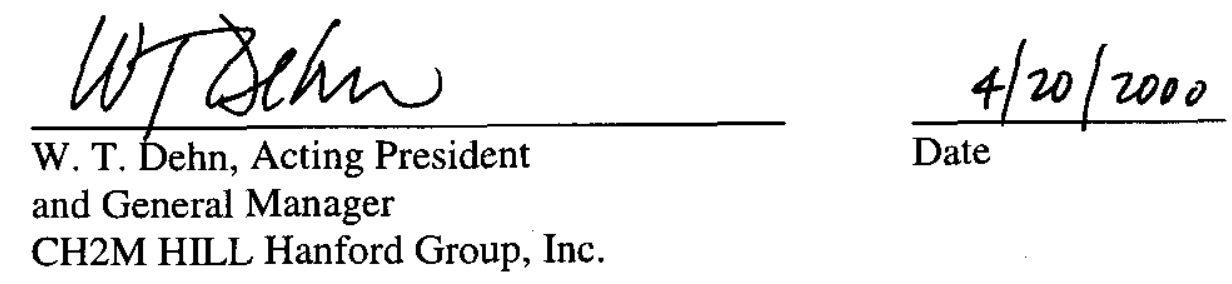
CH2M HILL Hanford Group, Inc. 


\section{RPP-6118 REV 0}

This page intentionally left blank. 


\section{RPP-6118 REV 0}

\section{EXECUTIVE SUMMARY}

This Readiness to Proceed Memorandum provides the CH2M HILL Hanford Group, Inc. (CHG), formal certification of readiness to proceed to support Phase 1 with waste feed delivery, privatization site infrastructure, and facilities to handle immobilized product storage and disposal. The declaration of readiness is based on CHG's planning, analysis, management systems, and experience with the tank farm infrastructure and disposal systems.

This memorandum discusses the approach taken to provide evidence of the Tank Farm Contractor (TFC) readiness to proceed for the Phase 1 Part B-2 decision and serves as the executive summary of the overall effort. The memorandum includes:

a. Key Assumptions

b. Critical risk list and mitigation (handling) actions

c. A summary of the financial and schedule risk analysis

d. A manageable list of deficiencies and a corrective action plan for each, including a date for closure.

This memorandum states that CHG can accomplish the following:

- Provide waste feed to the Privatization Contractor in the specified amounts to the specified place at the required time

- Provide infrastructure to the Privatization Contractor as specified in the final privatization contract and the Interface Control Documents (ICD)

- Be prepared for receiving, storing and disposing of immobilized waste products

- Be prepared for receiving, managing, treating, and disposing of currently planned byproducts (secondary wastes) from the Privatization Contractor

- Support reasonable alternatives other than the current baseline

- Complete required administrative actions (e.g., permits, etc.) so that they will be in place at the required time.

The CHG mission elements have been planned with $80 \%$ confidence of meeting the schedule need dates, as requested.

CH2M HILL Hanford Group, Inc., is pleased to certify that the TFC is Ready to Proceed to support the Phase 1 B-2 decision with waste feed delivery, privatization site infrastructure, and facilities to handle immobilized product storage and disposal. 


\section{CONTENTS}

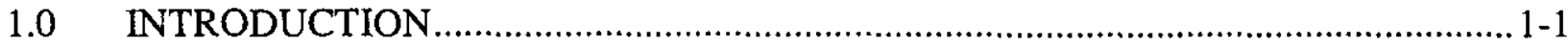

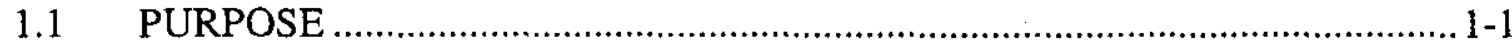

1.2 PREVIOUS DECLARATION OF READINESS ............................................ 1-1

1.3 CHANGES SINCE 1998 DECLARATION OF READINESS ..........................1-3

1.4 REQUIREMENTS FOR CERTIFICATION ……...........................................1-4

1.5 READINESS ASSESSMENT PROCESS ……............................................. 1-6

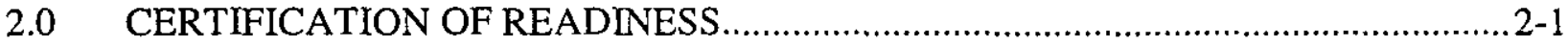

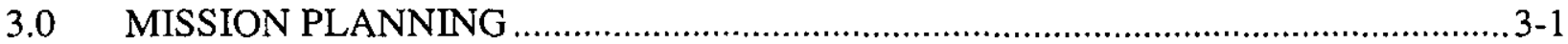

3.1 PLANNING GUIDANCE .....................................................................

3.2 INTEGRATED BASELINE ………….........................................................

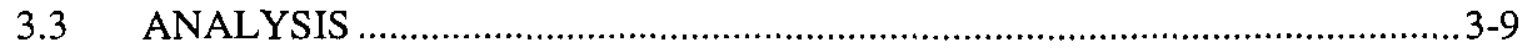

3.4 ABILITY TO SUPPORT ALTERNATIVES OTHER THAN THE

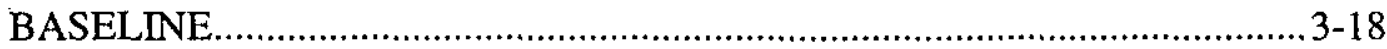

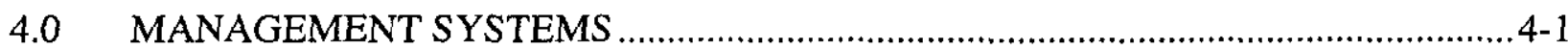

4.1 MANAGEMENT PLANS AND PROCEDURES.......................................... 4-1

4.2 KEY ENABLING ASSUMPTIONS AND CRITICAL RISKS ........................ 4-5

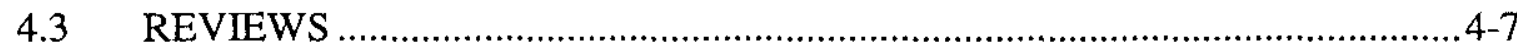

5.0 IDENTIFIED MANAGEMENT ISSUES, DEFICIENCIES AND CORRECTIVE ACTIONS....................................................................................................

5.1 RECOMMENDATIONS AND ACTIONS FOR OFFICE OF RIVER PROTECTION ATTENTION .....................................................................5:1

5.2 ISSUES FOR CH2M HILL HANFORD GROUP, INC. TO RESOLVE ............5-6

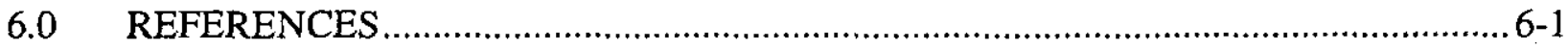

\section{APPENDICES}

A CH2M HILL HANFORD GROUP, INC., KEY ASSUMPTIONS ……………............ A-i

B CH2M HILL HANFORD GROUP, INC., CRITICAL RISKS ................................... B-i

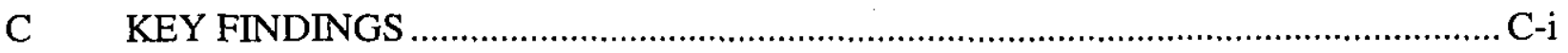




\section{RPP-6118 REV 0}

\section{FIGURES}

Figure 1-1. River Protection Project Mission Summary. $1-2$

Figure 3-1. Functional Components of the River Protection Project.

Figure 3-2. River Protection Project Mission Logic (River Protection Project Level 0 Logic). 3-3

Figure 3-3. River Protection Project Work Breakdown Structure. $3-5$

Figure 3-4. Integrated Baseline Development..... 3-8

Figure 3-5. Feed Delivery, Storage, and Disposal Mission Summary for 2006 Hot Start.

Figure 3-6. Feed Delivery, Storage, and Disposal Mission Summary for 2006 Hot Start Extended Order. $3-13$

Figure 4-1. CHG Organization Chart.

Figure 4-2. Tank Farm Contractor Document Structure. 4-3

\section{TABLES}

Table 1-1. Readiness To Proceed Document Deliverables. $1-5$

Table 1-2. Readiness To Proceed Certification Elements..................................................... 1-6

Table 3-1. Office of River Protection Baseline Guidance Schedules.

Table 3-2. Comparison of Readiness-to-Proceed Baseline Schedule with Office of River Protection Planning Guidance.

Table 3-3. Tank Farm Contractor Budget Analysis Summary FY 2000 through FY 2018.

Table 3-4. Schedule Analysis Summary. $3-16$

Table 3-5. CH2M HILL Hanford Group, Inc.; Fluor Hanford, Inc.; and Privatization Contractor Staffing Profile Summary.

Table 4-1. Other Documents Supporting Readiness to Proceed.

Table 4-2. Office of River Protection Criteria Requirements Analysis Document Review Issues and Resolution.

Table 4-3. Internal Independent Review Team Pre-Readiness-To-Proceed Review 


\section{RPP-6118 REV 0}

Table 5-1. Deficiencies and Corrective Actions for the Office of River Protection....................5-1

Table 5-2. Manageable Deficiencies and Associated Corrective Actions..................................5-6 


\section{TERMS}

$\begin{array}{ll}\text { A/E } & \text { architect/engineer } \\ \text { BNFL } & \text { BNFL Inc. } \\ \text { BUG } & \text { Baseline Update Guidance } \\ \text { CHG } & \text { CH2M HILL Hanford Group, Inc. } \\ \text { CRAD } & \text { Criteria Requirements Analysis Document } \\ \text { DOE } & \text { U.S. Department of Energy } \\ \text { DST } & \text { double-shell tank } \\ \text { EIR } & \text { External Independent Review } \\ \text { FH } & \text { Fluor Hanford, Inc. } \\ \text { FY } & \text { fiscal year } \\ \text { HLW } & \text { high-level waste } \\ \text { HTWOS } & \text { Hanford Tank Waste Operations Simulator } \\ \text { ICD } & \text { Interface Control Document } \\ \text { IHLW } & \text { immobilized high-level waste } \\ \text { ILAW } & \text { immobilized low-activity waste } \\ \text { IPPD } & \text { Integrated Process and Product Development } \\ \text { ISMS } & \text { Integrated Safety Management System } \\ \text { LAW } & \text { low-activity waste } \\ \text { LDR } & \text { land disposal restrictions } \\ \text { LMHC } & \text { Lockheed Martin Hanford Corporation } \\ \text { LOI } & \text { Lines of Inquiry } \\ \text { MYWP } & \text { multi-year work plan } \\ \text { ORP } & \text { Office of River Protection } \\ \text { OUP } & \text { Operations and Utilization Plan } \\ \text { PIO } & \text { Project Integration Office } \\ \text { QAPD } & \text { quality assurance program description } \\ \text { RCRA } & \text { Resource Conservation and Recovery Act of 1976 } \\ \text { RL } & \text { DOE, Richland Operations Office } \\ \text { RPP } & \text { River Protection Project } \\ \text { RTP } & \text { readiness to proceed } \\ \text { SEMP } & \text { Systems Engineering Management Plan } \\ \text { SST } & \text { single-shell tank } \\ \text { TBR } & \text { Technical Basis Review } \\ \text { TBSD } & \text { Technical Baseline Summary Description } \\ \text { TFC } & \text { Tank Farm Contractor } \\ \text { TPA } & \text { Tri-Party Agreement } \\ \text { WBS } & \text { work breakdown structure } \\ \text { WDOE } & \text { Washington State Department of Ecology } \\ & \\ & \end{array}$




\section{RPP-6118 REV 0}

This page intentionally left blank. 


\section{RPP-6118 REV 0}

\subsection{INTRODUCTION}

CH2M HILL Hanford Group, Inc. (CHG), is under contract to plan, manage, and execute the Tank Farm Contractor (TFC) projects and operations for the U.S. Department of Energy (DOE) Office of River Protection (ORP). In accordance with the contract, $\mathrm{CHG}$ is conducting business to meet the expected tank waste outcomes of the Hanford Strategic Plan. These actions include:

- Maintaining Tank Farms in a safe and stable configuration

- Delivering waste feed to the Privatization Contractor for treatment and immobilization

- Disposing of immobilized low-activity waste (ILAW) on Site in a 200 Area disposal system

- Storing the high-level immobilized waste until it can be shipped off Site for disposal (planned for the Yucca Mountain geologic repository).

In cooperation with ORP and BNFL Inc. (BNFL), CHG has assessed its readiness to proceed (RTP) with the detailed design and construction of facilities to retrieve, store, and dispose Hanford's tank waste. The River Protection Project (RPP) mission with the TFC and Privatization Contractor roles, is summarized in Figure 1-1. This Readiness to Proceed Memorandum, with the associated documents, is submitted for ORP's comprehensive review. The information describes that portion of CHG's scope necessary to support the waste feed delivery and immobilized waste disposal mission elements, while maintaining tank farms in a safe and stable configuration.

\subsection{PURPOSE}

The purpose of this document is to formally "certify that CHG has the ability to provide the waste feed and infrastructure to handle the products from the BNFL waste processing plant." (ORP 1999, CH2M HILL Hanford Group, Inc., Contract No. DE-AC06-99RL14047, Performance Incentive 4.5.1 R1.) In this certification CHG provides, or references, the evidence that:

- The mission is understood

- Plans exist to execute the mission

- Management systems and organization are in place to execute the plans.

\subsection{PREVIOUS DECLARATION OF READINESS}

In January of 1998, the TFC submitted its statement of RTP with Phase 1B Privatization (Borneman 1998). 


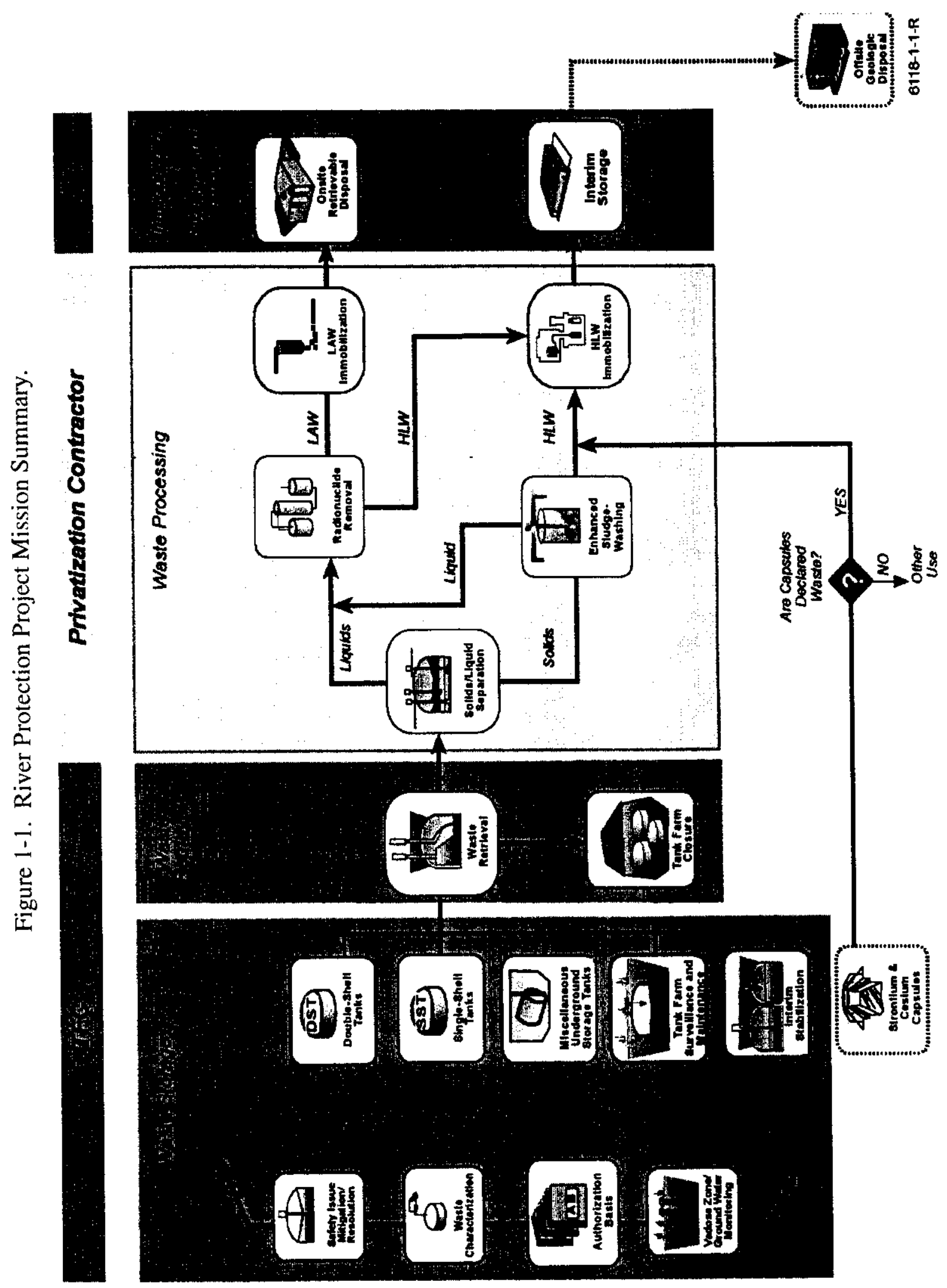


That memorandum, and the accompanying 1998 RTP evidence package, documented the results of planning and analysis leading to the conclusion;

“... the systems and infrastructure required to support the mission are known.

Required systems are either in place or plans have been developed to ensure they exist when needed. ... An analysis of programmatic, management, and technical activities necessary to declare RTP indicates that the system, personnel, and hardware will be on line and ready to support the private contractors."

The DOE concurred with the TFC's assessment (Taylor 1998). DOE also recognized eight "Major Recommendations on the RTP evidence package" that required action on the part of the TFC. CHG has proceeded with preparations to support the RPP mission. During this period, the eight DOE recommendations have been addressed (Wood 2000a).

\subsection{CHANGES SINCE 1998 DECLARATION OF READINESS}

The 1998 TFC's declaration of readiness was based on the 1996 DOE contract with two competing vendors to begin processing in 2002. In August 1998, the DOE signed a contract with one vendor, BNFL, to begin the design of pretreatment and low-activity waste (LAW) and highlevel waste (HLW) treatment and immobilization facilities. Evolution of the program has continued and number of technical and programmatic changes have occurred. This evaluation of RTP considers the following changes:

- Selected One Phase 1 Privatization Contractor instead of two

- Waste feed delivery plans and infrastructure projects were replanned as a result

- Revised facility configurations

- ORP is no longer providing a double-shell tank (DST) to the Privatization Contractor, for feed staging

- The ILAW disposal system will use a remote trench rather than modified grout vaults

- Modified construction and operations schedules

- LAW feed sequences have been reordered and facility ramp-up rates have been changed to meet the evolving requirements of the Privatization Contractor

- The start up dates for feed delivery, vitrification and product disposal have been revised to fit new contract dates for 2006 waste treatment plant hot commissioning 


\section{RPP-6118 REV 0}

- Adjusted scope between CHG and the Privatization Contractor

- Sludge washing will be performed in the vitrification facility by the Privatization Contractor rather than in double-shell tanks (DST) by the TFC

- Added more single-shell tank waste to the feed sequence

- The single-shell tank (SST) retrieval schedule is accelerated.

Other changes have influenced the execution of the baseline.

- The TFC became a prime contractor to DOE for execution of the RPP mission.

- CH2M HILL purchased the TFC and with the purchase obtained the tank farm contract.

- ORP established the Project Integration Office to coordinate the RPP mission and the multiple contractors.

- The RPP began using Integrated Process/Product Teams to work on interface agreements and issues.

- The TFC has demonstrated significant progress in operating the tank farms and resolving tank farm issues including: completion of the cross-site transfer line (W-058), removal of the high heat sludge from tank C-106, elimination of the flammable gas storage issue from tank SY-101, and implementation of a comprehensive tank farm safety Authorization Basis.

\subsection{REQUIREMENTS FOR CERTIFICATION}

The RTP evaluation objective includes demonstrating that the TFC can meet requirements to support the Privatization Contractor by providing the infrastructure and waste feed for immobilization and by receiving and managing the products and byproducts from the waste processing facilities. As part of the demonstration, ORP requested that $\mathrm{CHG}$ provide "Formal certification of the contractor's ability (Memorandum of Readiness to Proceed) to provide the waste feed and infrastructure to handle the products from the Privatization Contractor waste processing plant."

The specific documents that $\mathrm{CHG}$ is delivering in response to the ORP performance incentive are shown in Table 1-1.

Other specific elements that DOE requested as part of the formal certification, and their location in the RTP Deliverables, are shown in Table 1-2. 


\section{RPP-6118 REV 0}

Table 1-1. Readiness To Proceed Document Deliverables.

\begin{tabular}{|c|c|c|}
\hline Requested Documents & Document Title & Document \# \\
\hline $\begin{array}{l}\text { Readiness to Proceed } \\
\text { Memorandum }\end{array}$ & $\begin{array}{l}\text { Memorandum of Readiness to Proceed with } \\
\text { Phase I Privatization for the Tank Farm } \\
\text { Contractor }\end{array}$ & $\begin{array}{l}\text { RPP-6118 } \\
\text { (Honeyman and Voogd } \\
2000 \text { ) }\end{array}$ \\
\hline $\begin{array}{l}\text { Integrated Resource Loaded } \\
\text { Schedule }\end{array}$ & $\begin{array}{l}\text { Programmatic Baseline Summary for Phase I } \\
\text { Privatization for the Tank Farm Contractor }\end{array}$ & $\begin{array}{l}\text { HNF-1946 } \\
\text { (Diediker 2000) }\end{array}$ \\
\hline $\begin{array}{l}\text { Tank Farm Contractor Operation } \\
\text { and Utilization Plan }\end{array}$ & $\begin{array}{l}\text { Tank Farm Contractor Operation and } \\
\text { Utilization Plan }\end{array}$ & $\begin{array}{l}\text { HNF-SD-WM-SP-012 } \\
\text { (Kirkbride 2000) }\end{array}$ \\
\hline Staffing Plan & $\begin{array}{l}\text { Human Resources Staffing Plan for the Tank } \\
\text { Farm Contractor }\end{array}$ & $\begin{array}{l}\text { RPP-6114 } \\
\text { (Bosley 2000) }\end{array}$ \\
\hline Configuration Management Plan & $\begin{array}{l}\text { Configuration Management Plan for the Tank } \\
\text { Farm Contractor }\end{array}$ & $\begin{array}{l}\text { HNF-1900 } \\
(\text { Weir 2000) }\end{array}$ \\
\hline Quality Assurance Program Plan & $\begin{array}{l}\text { Quality Assurance Program Description for the } \\
\text { Tank Farm Contractor }\end{array}$ & $\begin{array}{l}\text { RPP-MP-600 } \\
\text { (Hebdon 2000) }\end{array}$ \\
\hline \multirow[t]{2}{*}{ Safety Program Plan } & $\begin{array}{l}\text { Integrated Environment, Safety and Health } \\
\text { Management System Description for the Tank } \\
\text { Farm Contractor }\end{array}$ & $\begin{array}{l}\text { HNF-MP-003 } \\
\text { (CHG 2000b) }\end{array}$ \\
\hline & $\begin{array}{l}\text { RPP Administration, "Health and Safety } \\
\text { Program Description" }\end{array}$ & $\begin{array}{l}\text { HNF-IP-0842, Vol. IX, } \\
\text { Section } 1.1 \\
\text { (CHG 2000d) }\end{array}$ \\
\hline Environmental Program Plan & $\begin{array}{l}\text { Environmental Program Description for the } \\
\text { Tank Farm Contractor }\end{array}$ & $\begin{array}{l}\text { HNF-1773 } \\
\text { (Powell 2000) }\end{array}$ \\
\hline Technical Baseline Summary & $\begin{array}{l}\text { Technical Baseline Summary Description for } \\
\text { the Tank Farm Contractor }\end{array}$ & $\begin{array}{l}\text { HNF-1901 } \\
\text { (Tedeschi 2000) }\end{array}$ \\
\hline Draft Project Execution Plan & $\begin{array}{l}\text { Draft Project Execution Plan for the Tank Farm } \\
\text { Contractor }\end{array}$ & $\begin{array}{l}\text { RPP-6017 } \\
\text { (Halverson 2000) }\end{array}$ \\
\hline $\begin{array}{l}\text { Letter Report on resolution of the } \\
\text { eight "Major Recommendations } \\
\text { on the RTP evidence package" } \\
\text { from previous RTP }\end{array}$ & $\begin{array}{l}\text { "Contract No. DE-AC06-99RL14047, River } \\
\text { Protection Project Fiscal Year 2000 } \\
\text { Performance Incentive ORP 4.5.1, Revision 1," } \\
\text { "Phase 1 Part B-2 Readiness to Proceed, } \\
\text { Section 3, Standard 3, and Section 4, Standard } 2\end{array}$ & $\begin{array}{l}\text { CHG-0002228 } \\
\text { (Wood 2000b) }\end{array}$ \\
\hline
\end{tabular}

ORP $=$ Office of River Protection.

RTP $=$ Readiness to Proceed. 
Table 1-2. Readiness To Proceed Certification Elements.

\begin{tabular}{|l|l|}
\hline \multicolumn{1}{|c|}{ Certification Elements } & \multicolumn{1}{c|}{ Location } \\
\hline CHG Key Assumptions & RPP-6118, Appendix A \\
\hline CHG Critical Risks & RPP-6118, Appendix B \\
\hline Financial and Schedule Risk Analysis & RPP-6118, Section 3.0 \\
\hline $\begin{array}{l}\text { Manageable List of Deficiencies, Corrective } \\
\text { Action Plan for each, including date for closure }\end{array}$ & RPP-6118, Section 5.0 \\
\hline Criteria Review Assessment Document Crosswalk & RPP-6118, Section 4.0 \\
\hline
\end{tabular}

The DOE also requested that the memorandum state that the TFC can:

- Provide waste feed to the Privatization Contractor in the specified amounts to the specified place at the required time

- Provide infrastructure to the Privatization Contractor as specified in the final privatization contract and the Interface Control Documents (ICD)

- Ensure that it will be prepared for receiving, storing, and disposing of immobilized waste products

- Ensure that it will be prepared for receiving, managing, treating, and disposing of byproducts from private contractors

- Ensure that the contractor can support alternatives other than the current baseline

- Ensure required administrative actions (e.g., permits, etc.) are in place.

This memorandum provides the statements and evidence that $\mathrm{CHG}$ can accomplish these mission activities.

\subsection{READINESS ASSESSMENT PROCESS}

CHG used a systematic approach to determine RTP with the next phase of this mission. That process included:

- Evaluation of the ORP criteria requirements analysis documents (CRAD)

- Evaluation of the External Independent Review (EIR) Lines of Inquiry (LOI)

- Review of existing systems with internal and external review groups

- Update of the baseline to address planning changes

- Analysis of the planning change impacts

- Updates to the management systems needed to support the mission.

These steps lead to preparation of the information provided to ORP for this RTP. 


\section{RPP-6118 REV 0}

Section 3.0 presents the results of the mission planning, development of an updated cost and schedule baseline, and analysis of that updated baseline.

Section 4.0 provides a discussion of the management systems needed to execute the mission plans. It discusses the management system documents that were updated for submittal and reviews to verify that management systems were working. Section 4.0 also addresses enabling assumptions and critical risks.

Section 5.0 addresses issues identified by management assessments with the follow on actions to assure the success of the Phase 1 mission. 
RPP-6118 REV 0

This page intentionally left blank. 


\subsection{CERTIFICATION OF READINESS}

CHG declares it is ready to proceed to support the RPP Phase 1 mission as required by contract and further defined in the ORP fiscal year (FY) 2000 multi-year work plan (MYWP) and corresponding performance incentive (ORP 1999). CHG will be ready to deliver waste feed to the Waste Treatment Plant, within specification, February 2006.

CHG has evaluated the TFC baseline, management systems, existing and planned hardware relative to the mission requirements, funding and field operations. The TFC portion of the Phase 1 mission is largely an extension of current operations for the TFC. An updated resourceloaded schedule has been established, and the required systems, staff, and documentation either are in place or plans have been developed to ensure that they will be in place when needed. Plans confirm that the TFC will be able to sustain feed delivery, infrastructure support, and receipt and eventual disposal of immobilized and other waste products for the duration of Phase 1 (i.e., through FY 2018). CHG confirms that the support and services (e.g., secondary waste treatment) needed for the tank waste retrieval and disposal mission and those that will be provided by members outside the TFC, are planned consistent with the scope, schedule, and cost in the RPP baseline, and that clear lines of communication and interface controls exist, or are being developed.

The planning assumptions required to construct HNF-1946, Programmatic Baseline Summary for Phase 1 Privatization for the Tank Farm Contractor (Diediker 2000) were derived from "Contract No. DE-AC06-99RL14047 - The U.S. Department of Energy, Office of River Protection (ORP) Mission Planning Guidance for Fiscal Year (FY) 2002 - Revision 1" (Short 2000) and CH2M HILL Hanford Group, Inc., Contract No. DE-AC06-99RL14047 (ORP 1999). The CHG Key Assumptions are provided in Appendix A. A comparison of the updated ORP planning assumptions (Barrett 2000) and the updated RTP baseline was completed. No significant discrepancies were discovered.

Budget and resource requirements, including staffing, have been estimated for Phase 1 of the tank waste retrieval and disposal mission. A financial analysis indicated that there is a high degree of confidence that the work required to meet key retrieval and disposal startup dates in 2006 can be carried out per the planned schedule with an $80 \%$ confidence of meeting a baseline estimate of $\$ 4,146 \mathrm{M}$ (escalated) through the Phase 1 period analyzed (FY 2000 through FY 2018).

Management, management systems, and Integrated Safety Management Systems exist to support the tank waste retrieval and disposal mission. CHG has demonstrated the ability to manage large, complex projects and has brought their corporate expertise to bear on this mission. The CHG contract is definitive and provides the vehicle to clearly communicate and control the scope.

Risk associated with the tank waste retrieval and disposal mission scope is manageable. Risks associated with technical, environmental, safety, health, cost, schedule, and management aspects of the updated baseline were evaluated at the working level of the work breakdown structure (WBS) and rolled up to the major mission-element level. Cross-cutting risks and technical risks of a programmatic nature also were considered. Mitigation measures were incorporated into the 


\section{RPP-6118 REV 0}

updated baseline to provide an acceptable probability of achieving technical, schedule, and cost expectations. Critical risks and the planned mitigation are provided in Appendix B.

CHG's confidence and credibility in planning and executing complex field tasks, has matured significantly during the last three years. These tasks involved the full range of activities necessary to upgrade tank farms, mix and retrieve waste, characterize feed, and transfer it.

Highlights of our success include:

\section{Safety Issue Resolution}

1. Closure of organic, high heat, criticality safety issues, and Unreviewed Safety Questions

2. Implementation of the Final Safety Analysis Report

3. Closure of the Flammable Gas Unreviewed Safety Question

4. Integrated Safety Management System Phase II verification.

\section{Significant Field Execution (Operations)}

1. Characterizing 134 of 177 tanks

2. Retrieving the wastes from high-heat tank $241-\mathrm{C}-106$

3. Resolving the crust growth safety issue with 241-SY-101 by installing transfer system and then retrieving and transferring waste and then back diluting 241-SY-101

4. Removing pumpable liquids from single-shell tanks ahead of schedule defined in the consent decree

5. Installing a Resource Conservation and Recovery Act of 1976 (RCRA) compliant crosssite transfer system and completing several large volume transfers from 200 West to 200 East areas.

\section{TFC Project Management}

1. The TFC successfully managed over $\$ 300 \mathrm{M}$ of work per year in FY 1998 and FY 1999 . This work was performed $\$ 37.1 \mathrm{M}(6 \%)$ under budget and with only a minor schedule variance $(\$ 8.4 \mathrm{M}, 1.3 \%)$.

These accomplishments represent a strong base of performance achieved by the TFC. The ability to plan, schedule, and execute complex operational evolutions is one of the key elements of success for the ORP.

In addition, substantial capital facility construction will be necessary to meet the feed delivery requirements, provide infrastructure, and store and dispose of the immobilized products. Between FY 2000 and waste treatment plant hot commissioning in FY 2006 approximately \$1 B 


\section{RPP-6118 REV 0}

of construction and project integration work must be successfully completed to support ORP's overall objectives.

Strong operational performance was one of the reasons that CH2M HILL decided to purchase the Lockheed Martin Hanford Corporation (LMHC) in December 1999. CH2M HILL is a worldclass Project Delivery company, with world-wide experience and success in innovating, planning, constructing, and completing complex environmental projects for a wide variety of clients. The skills brought by CH2M HILL are complementary to the talent and skill already apparent in the TFC's efforts over the last 3 years.

CH2M HILL Hanford Group, Inc., is ready to proceed with Phase 1 of the River of Protection Project mission. 


\section{RPP-6118 REV 0}

This page intentionally left blank. 


\subsection{MISSION PLANNING}

The RPP consists of five major functional components as illustrated in Figure 3-1. Waste Storage, Waste Retrieval, Immobilized Waste Disposition, and Immobilization Support, are performed by CHG. The Waste Immobilization function is performed by the Privatization Contractor. Shown in Figure 3-1 are internal and external interfaces, with reference numbers to the ICDs. The Offsite HLW Repository, Site Support Services, and the Groundwater/Vadose Zone Project are also identified.

The mission has been identified in logic diagrams that are based on schedules for accomplishing the scope. The RPP Mission Logic diagram, TWR-2086, Figure 3-2 is a tool for translating the RPP mission requirements identified in the River Protection Project Mission Analysis Report (ORP 2000a) into a sequence of activities necessary to achieve the mission objectives. Figure 3-2 illustrates the major work that the RPP must perform to accomplish its mission, including safe storage, waste immobilization (Phase 1), waste immobilization and disposal completion (Phase 2), and closure. The logic also illustrates how the Privatization Contractor activities integrate with the other contractor activities by way of the linkages to the Privatization Contractor in Phase 1.

The RPP work breakdown structure has been organized programmatically into ten elements as a common framework for work planning and integration of the project baseline. The work breakdown structure is shown in Figure 3-3. This RTP assessment focuses on the subset of activities within the WBS needed to support the Privatization Contractor. This subset is the Phase 1 tank waste retrieval and disposal mission, which includes the following WBS elements and portions of:

TW-01 Characterization in Support of Retrieval, within Tank Waste Characterization

TW-03 Project W-314, within Tank Farm Operations

TW-04 Waste Retrieval

TW-05 Interface Management, within Process Waste Support

TW-08 Infrastructure

TW-09 Immobilized Waste.

The entire Phase 1 RPP budget estimate is also reported here for comparison.

\subsection{PLANNING GUIDANCE}

ORP established the feed sequence and the associated dates for delivery of the initial LAW and HLW feed (French 2000). ORP then supplemented this information in the FY 2002 planning guidance (Short 2000). This guidance provided additional information necessary for tank waste 
RPP-6118 REV 0

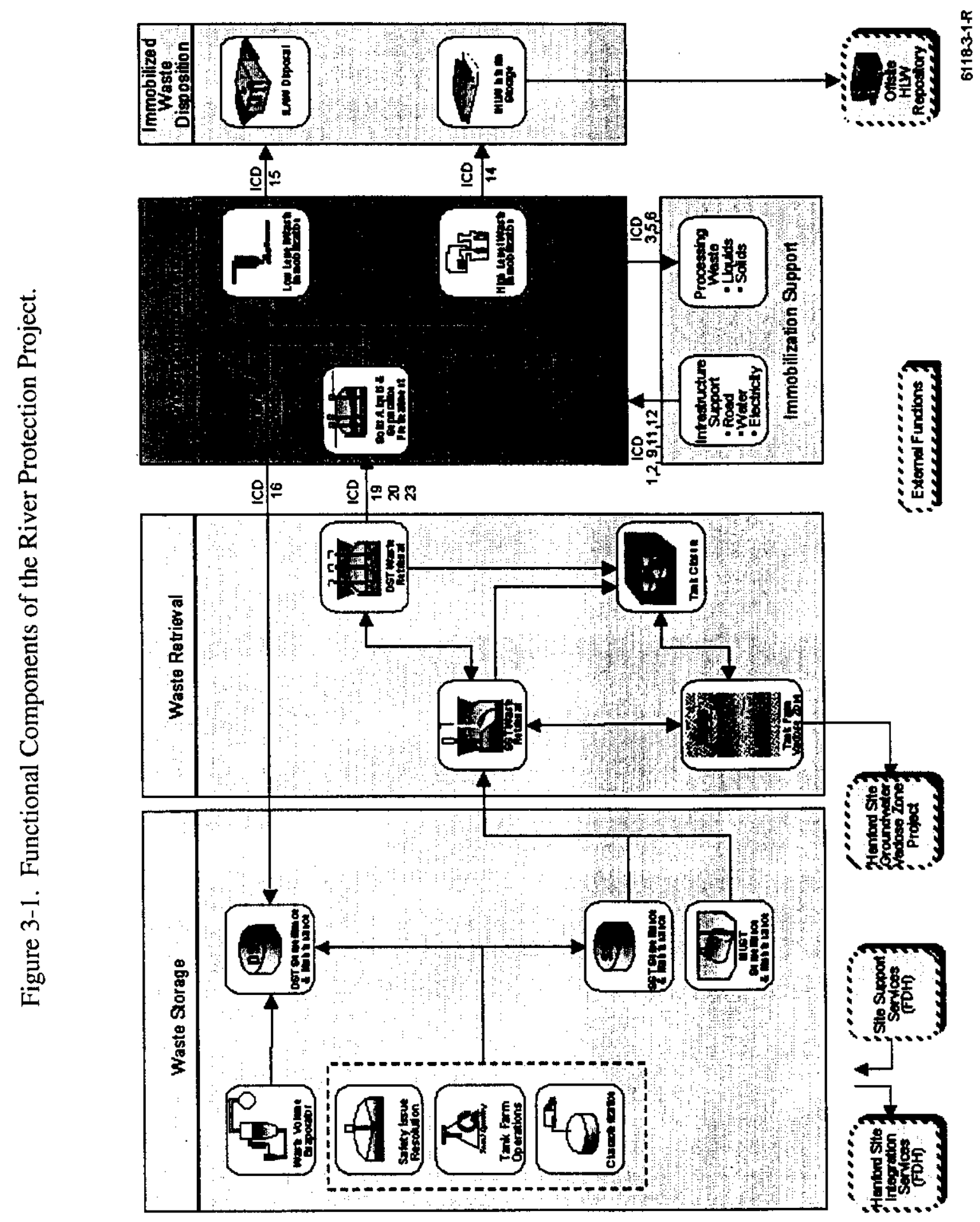




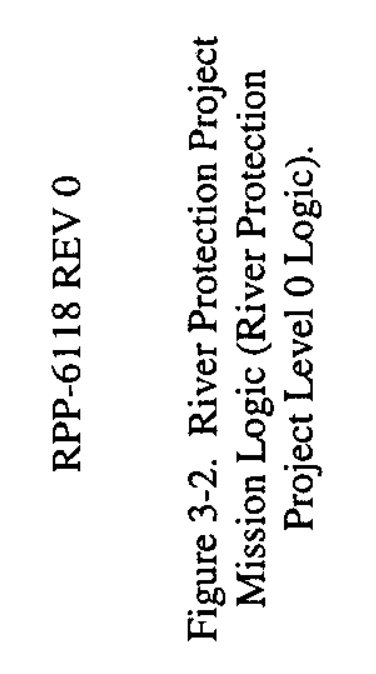

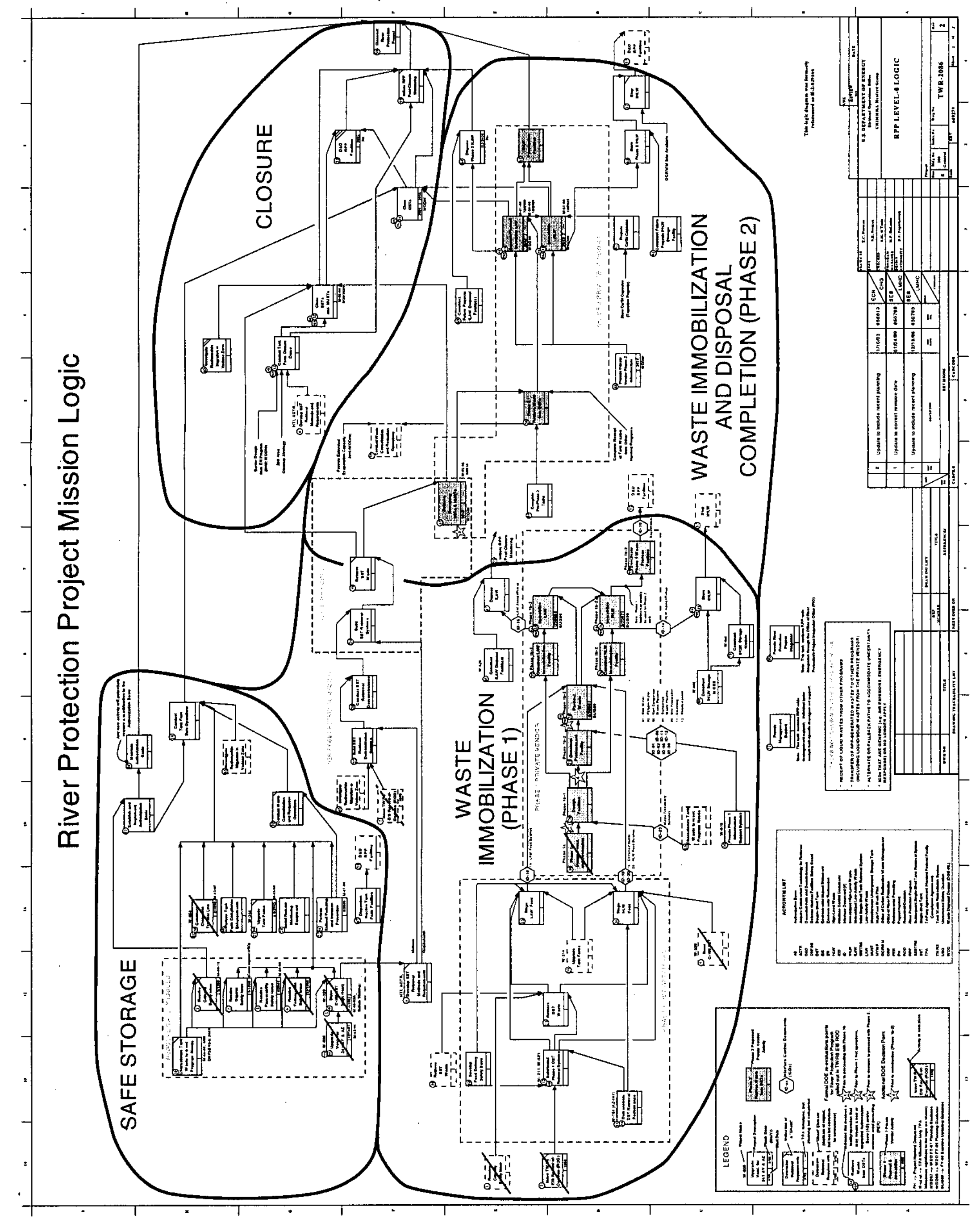




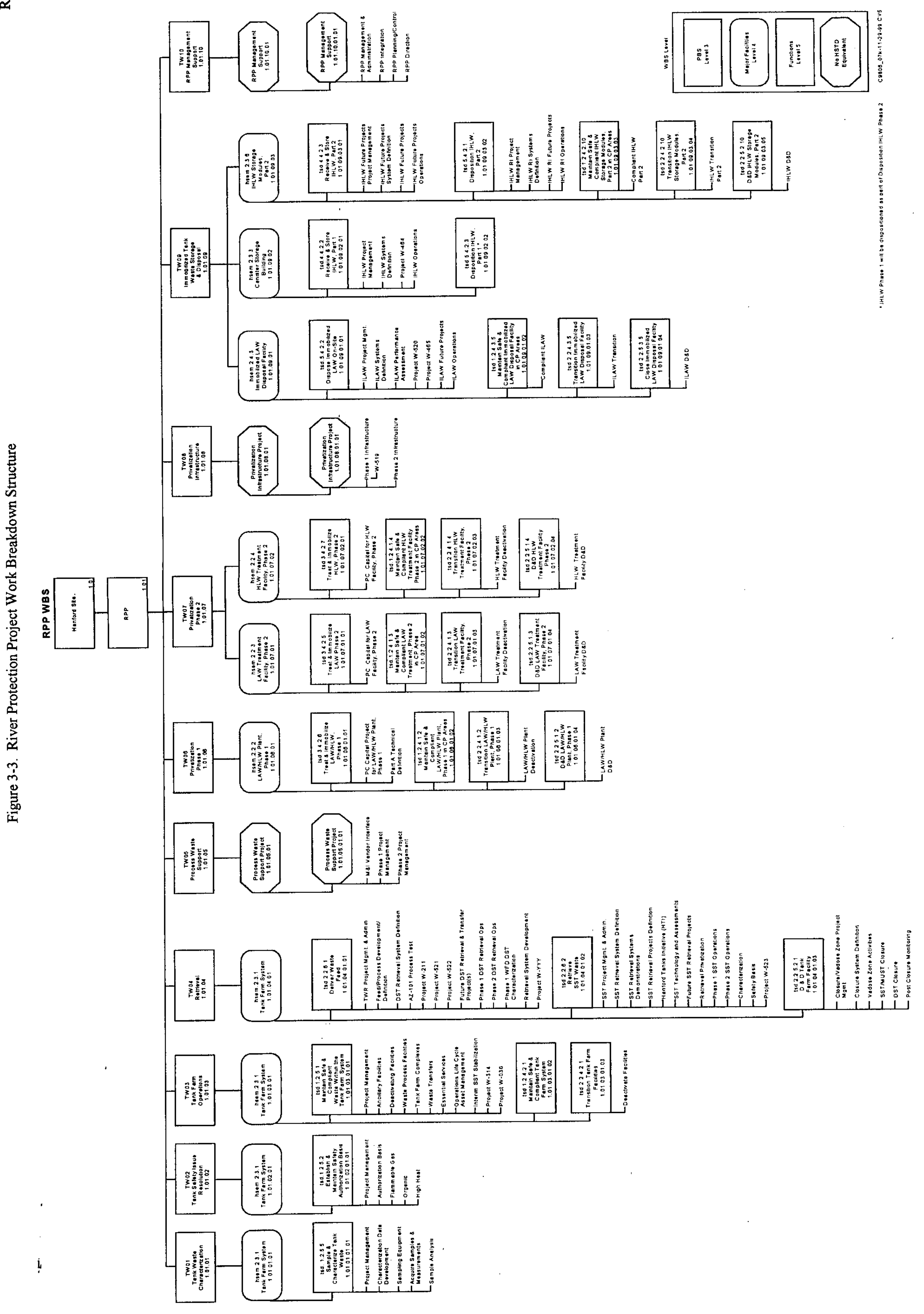


retrieval and disposal planning with emphasis on priorities for the full RPP mission. CHG's plan for the Phase 1 retrieval and disposal mission was developed based on this guidance.

Subsequently, ORP provided additional assumptions that have been used to support the RTP analysis (Barrett 2000).

Critical items from this set of key planning assumptions are:

- FY 2001 funds are constrained to $\$ 382.1 \mathrm{M}$. Budget/fund levels are unconstrained from FY 2002 through the end of the mission and are tied to full compliance requirements.

- Planning bases for feed delivery sequence and rates for both LAW and HLW minimum order are specified.

- Key startup dates were provided by ORP. These are listed in Table 3-1.

Table 3-1. Office of River Protection Baseline Guidance Schedules.

\begin{tabular}{|l|l|}
\hline \multicolumn{1}{|c|}{ Key Startup Dates } & \\
\hline a. Delivery of first LAW batch initiated & February 28, 2006 \\
\hline b. First batch of LAW delivered & April 30, 2006 \\
\hline c. Delivery of first HLW batch initiated & August 31, 2006 \\
\hline d. First batch of HLW delivered & October 31, 2006 \\
\hline $\begin{array}{l}\text { e. } \text { Delivery of first batch from second HLW staging } \\
\text { tank initiated }\end{array}$ & January 31, 2008 \\
\hline f. First batch from second HLW staging tank delivered & March 31, 2008 \\
\hline g. Earliest date delivery of first AN-102 batch is initiated & December 31, 2008 \\
\hline h. Earliest date first AN-102 batch is delivered & February 28, 2009 \\
\hline i. Start LAW facility hot commissioning & November 30, 2006 \\
\hline j. Start HLW facility hot commissioning & May 31, 2007 \\
\hline k. Start LAW hot vitrification services & March 1, 2008 \\
\hline l. Start HLW hot vitrification services & September 1, 2008 \\
\hline $\begin{array}{l}\text { FY = fiscal year. } \\
\text { HLW = high-level waste. } \\
\text { LAW = low-activity waste. }\end{array}$ \\
\hline
\end{tabular}

\subsection{INTEGRATED BASELINE}

CHG maintains a life-cycle integrated baseline of the technical, workscope, schedule, and cost requirements supporting the Phase 1 mission. The integrated baseline planning is a process that guides the project in the development of a consistent, efficient, and effective means for successful project performance and delivery. This integrated baseline planning process is depicted in Figure 3-4. 


\section{RPP-6118 REV 0}

Figure 3-4. Integrated Baseline Development.

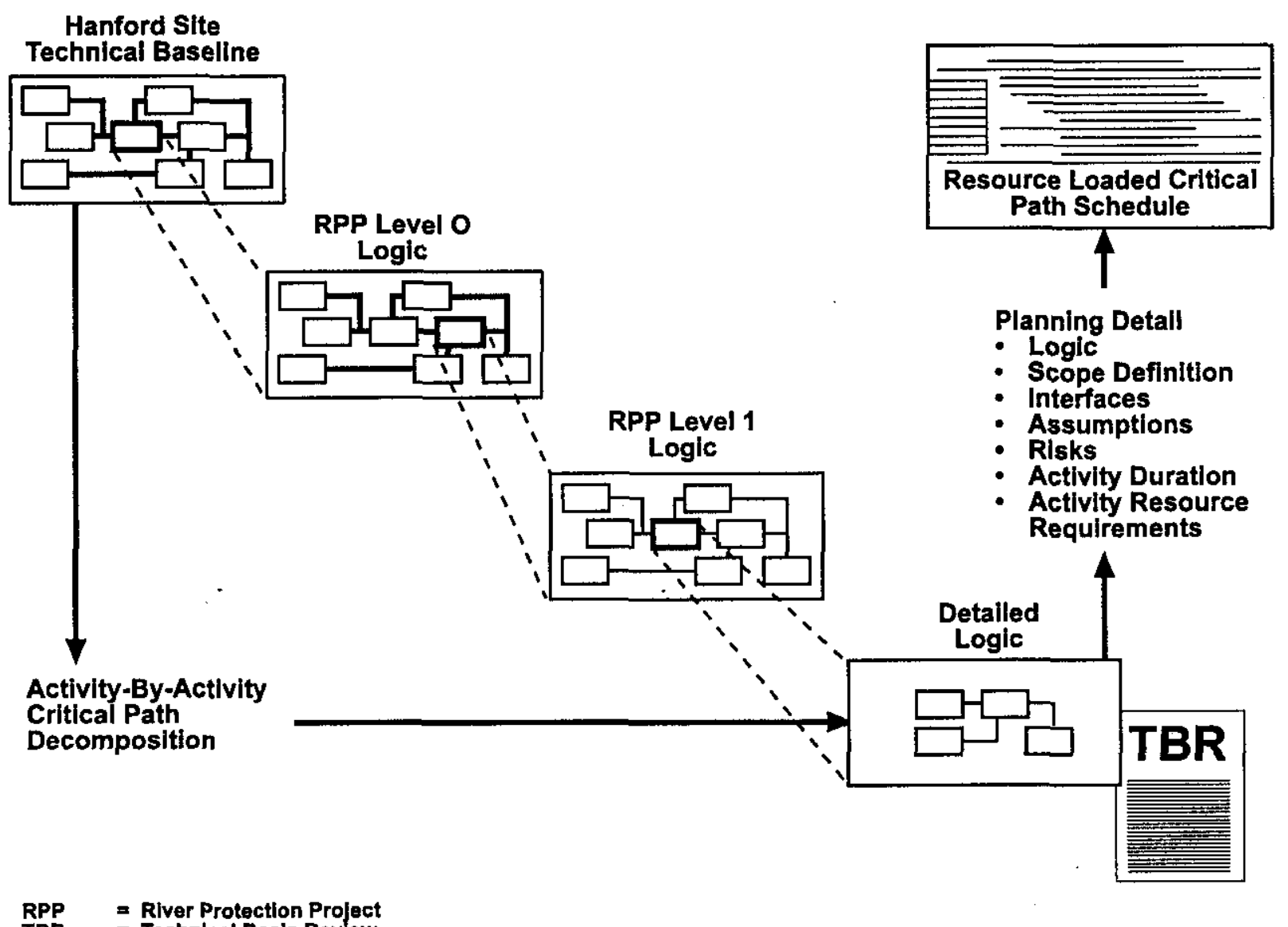

RBR $\quad=$ River Protection Project

Technlcal Basis Review

2019-5-3-R

As noted in Section 3.0, overall workflow and sequence for the RPP is depicted in the RPP Mission Level 0 Logic (Figure 3-2). This logic identifies approximately 100 sequentially linked, broadly scheduled activities necessary to achieve the technical requirements of the mission. The RPP Mission Logic is the top-level basis for the RTP planning. CHG key assumptions were developed to bound scope and establish a basis for planning. The key assumptions were derived from DOE reference documents and are included in Appendix A.

The TFC used activity-based planning to define work scope and developed Level 1 Logics, which depict unique activities, logical interdependencies, and sequence of the technical scope necessary to achieve the tank waste retrieval and disposal mission. The diagrams identify logic, interface, scope, and support the detailed Technical Basis Review (TBR) packages generated for each activity identified on the Level 1 Logics. The updated logics are provided in HNF-1946, Programmatic Baseline Summary for Phase 1 Privatization for the Tank Farm Contractor (Diediker 2000).

The TBRs provide the lower levels of the schedule logic. The TBRs document the definition of work to be performed, interface requirements, assumptions, risks, skills and resources required to perform the work, organizational responsibilities for work performance, and defines how and when the work will be executed. Activity-based cost estimates are prepared at the lowest practical level of detail and include estimate basis, assumptions, and exclusions for each TBR. 


\section{RPP-6118 REV 0}

The formal documentation captured in the TBR packages is used to produce a task-oriented, logic-driven, resource-loaded, critical path schedule. The integrated resource-loaded schedule provides a time-phased plan with a logical sequence of interdependent activities, milestones, and constraints. More than 12,000 schedule and cost-estimated activities are included in the proposed baseline schedule. This level of detail substantiates feed delivery, storage, and disposal, the rigor and depth of $\mathrm{CHG}$ 's planning for waste feed delivery. Financial information is presented in the Baseline Summary (Diediker, 2000).

The Mission Summary Diagram provides a graphical summary of the detailed schedules for the Retrieval, Projects, and Operations mission and reflects the operating scenario and sequence of waste retrieval and delivery to the Privatization Contractor. Detailed planning assumptions and information on tank waste composition, existing or planned equipment, and operational capabilities are defined in HNF-SD-WM-SP-012, Tank Farm Contractor System Operation and Utilization Plan (Kirkbride 2000). The Mission Summary Diagram is shown in Figures 3-5 and 3-6.

The integrated baseline schedule and TBR documentation is key to conducting the financial and risk analyses. Risks were derived from detailed planning and linked to the RPP mission analysis, program logics, and critical path schedule assessment. The TFC project management team utilizes risk management strategy throughout the project life cycle. Mitigating actions and plans exist, with identified responsible parties, to manage each identified risk event. Detailed risk management process and results are documented in the Financial Analysis for Phase 1 Privatization for the Tank Farm Contractor, HNF-2017, Rev 2 (Basche 2000). Critical risks are further discussed in Section 4.2.

\subsection{ANALYSIS}

The updated RTP baseline was evaluated for technical conformance with guidance, financial risk (cost and schedule), and ability to manage staffing mission requirements.

\subsubsection{Technical Analysis}

In March, 2000 ORP modified its planning assumptions to eliminate sulfate removal from the vitrification flowsheet. This resulted in a decrease in the assumed sodium oxide loading of envelope B waste from $19.5 \%$ to $7.5 \%$ in the ILAW. These assumptions were formally transmitted to CHG on April 10, 2000, (Barrett 2000). CHG has performed a comparative analysis of the proposed updated Baseline Summary (Diediker 2000) with this ORP guidance using the Hanford Tank Waste Operations Simulator (HTWOS). A summary of the technical findings is included in Appendix C. These findings show that the need dates can be met for feed delivery and product storage and disposal. A more detailed discussion of this comparison can be found in the Tank Farm Contractor Operations and Utilization Plan (Kirkbride 2000). 


\section{RPP-6118 REV 0}

This page intentionally left blank. 


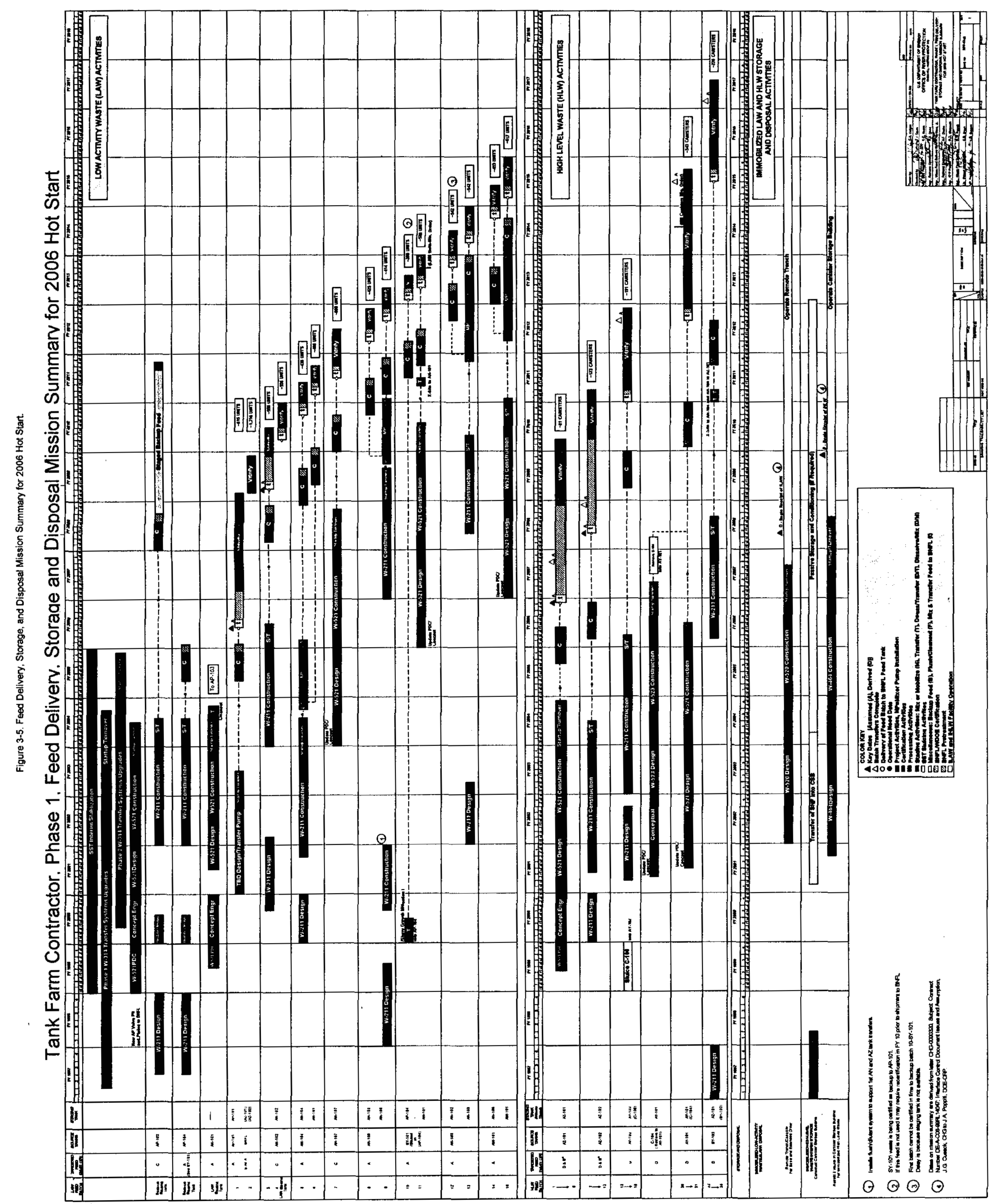




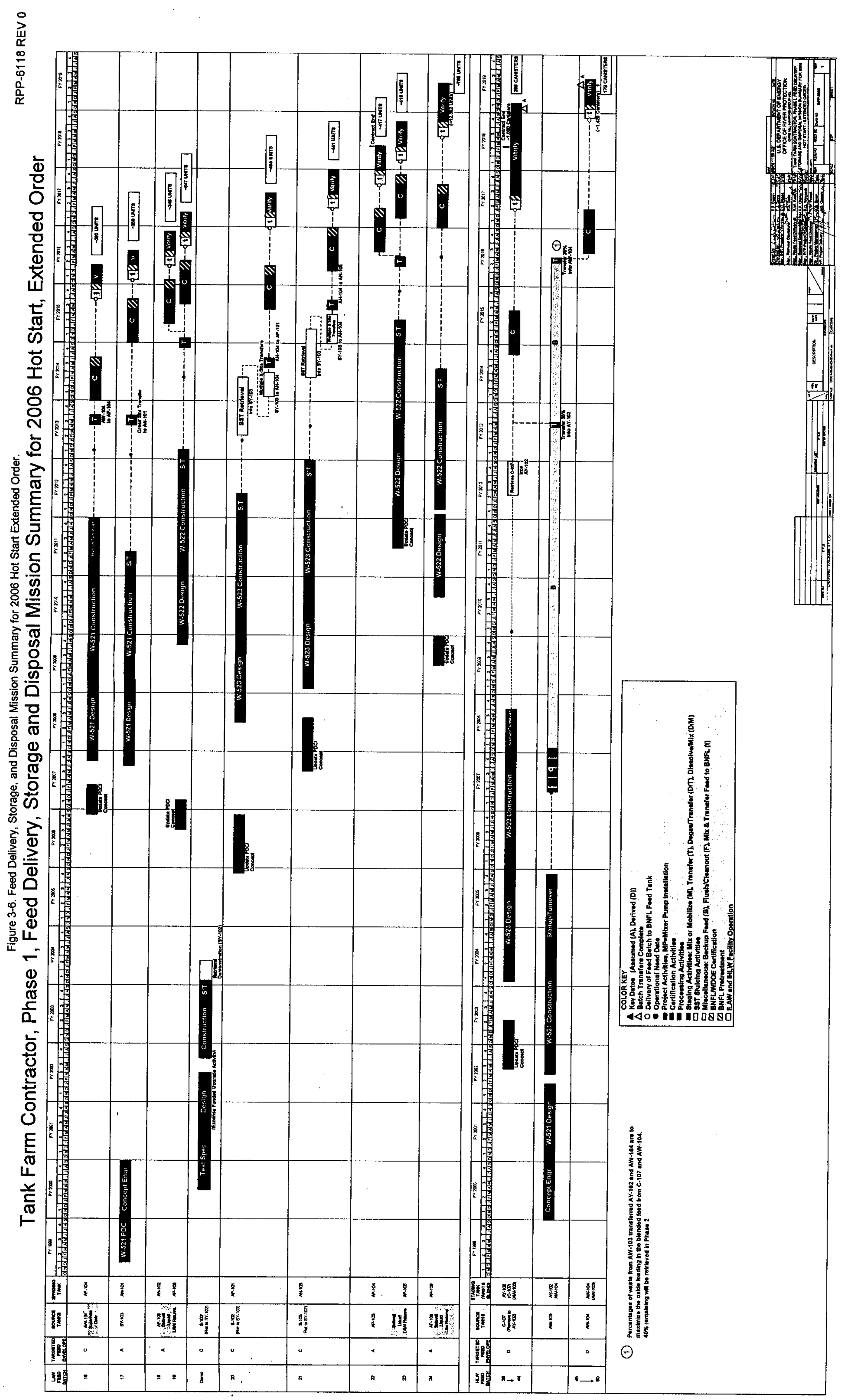


Table 3-2 compares the dates that were provided in the ORP guidance (Barrett 2000) with the corresponding dates included in the proposed updated baseline schedule as shown on the Mission Summary Diagram (Figures 3-5 and 3-6). In all cases the proposed updated baseline completes construction and the necessary operational evolutions in advance of the guidance dates.

Table 3-2. Comparison of Readiness-to-Proceed Baseline Schedule with Office of River Protection Planning Guidance.

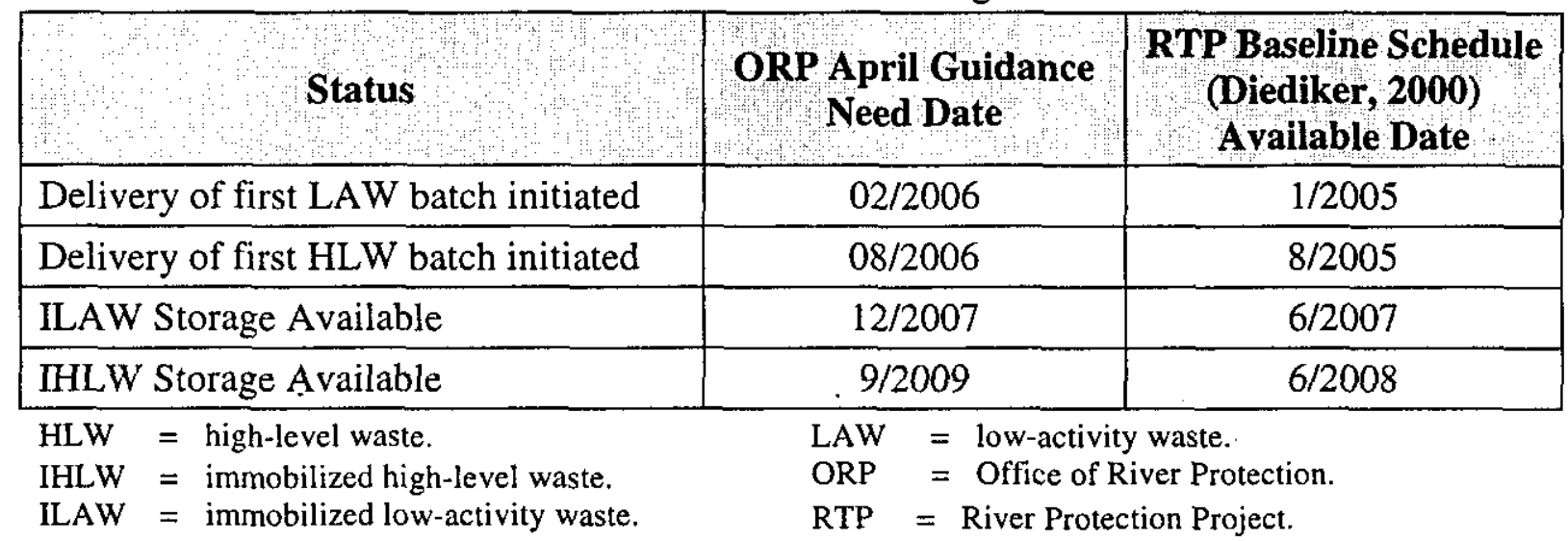

The analysis shows the feed, storage, and disposal systems will be available as required. The issue associated with feed envelopes is discussed in Section 5.1. The quantity delivered in accordance with the Feed Staging Strategy meets the minimum and extended order quantities for LAW and HLW.

Infrastructure is being put into place to support the RPP by Project W-519, TWRS Privatization Phase 1 Infrastructure Support. Project specifications and schedule progress provide confidence that the necessary infrastructure (water, electricity and roads) will be in place in time and consistent with the privatization contract and associated infrastructure ICDs. The analysis also considered the quantities, schedule and compositions of byproducts received from the Privatization Contractor as defined by the contract and ICDs. Related cases were analyzed by the simulator models.

\subsubsection{Financial Analysis}

A financial analysis was performed to document the results of the risk-based analysis (Basche 2000). The analysis addressed the executability of the proposed baseline cost and schedule and recommended program additions to meet the $80 \%$ probability of success target required by (Short 2000) and (Barrett 2000).

The tank waste retrieval and disposal total unescalated budget requirements are $\$ 3,528 \mathrm{M}$ including other adjustments of $\$ 288 \mathrm{M}$ and $\$ 66 \mathrm{M}$ risk adjustment (see HNF-2017 [Basche 2000]) for detailed explanation of cost adjustments). The risk-based cost analysis suggests an allowance of $\$ 66 \mathrm{M}$ above the baseline to achieve the desired $80 \%$ probability of success. With escalation, this total budget is $\$ 4,146 \mathrm{M}$. The costs for Phase 1 and the balance of the mission are presented 
in Table 3-3. The updated escalated total RPP budget requirement excluding the Privatization Contractor portion over the Phase 1 life (FY 2000 through FY 2018) is approximately $\$ 17$ B.

Table 3-3. Tank Farm Contractor Budget Analysis Summary FY 2000 through FY 2018.

\begin{tabular}{|c|c|c|}
\hline & $\begin{array}{c}\text { Retrieval and } \\
\text { Disposal Phase 1 } \\
\text { FY00 - FY18 }\end{array}$ & $\begin{array}{c}\text { CHG Total } \\
\text { Program } \\
\text { FY00-FY18 }\end{array}$ \\
\hline Updated Baseline Budget & $\$ 3,174$ & $\$ 12,987$ \\
\hline Additional Risk Allowance (not previously included) & 66 & 66 \\
\hline Budget Adjustments & 288 & 697 \\
\hline Subtotal & 3,528 & $\$ 13,750$ \\
\hline Escalation & 618 & $\$ \quad 3,387$ \\
\hline Total & 4,146 & $\$ 17,137$ \\
\hline
\end{tabular}

CHG $=$ CH2M HILL Hanford Group, Inc.

$\mathrm{FY}=$ fiscal year.

The risk-based schedule analysis provided confirmation that the required schedule could be met with an acceptable probability of success. Table $3-4$ contains the predicted $80 \%$ confidence completion dates of selected key events. Note that the dates determined by the probabilistic analysis at $80 \%$ confidence level are different than the baseline schedule dates shown in Table 3-2. However, the $80 \%$ confidence dates are all earlier than the need dates. Thus the risked-based analysis demonstrates the acceptability of the proposed schedule. Capital project portions of the program already have contingency incorporated in their baselines so no additional cost and schedule risk analysis was completed on this portion of the Phase 1 lifecycle budget. Management systems costs also were not evaluated because they are essentially level-of-effort activities and do not contain significant technical or programmatic risks.

Table 3-4. Schedule Analysis Summary.

\begin{tabular}{|l|c|c|}
\hline & $\begin{array}{c}\text { ORP April } \\
\text { Guidance Need } \\
\text { Date }\end{array}$ & $\begin{array}{c}\text { Target Date in Proposed } \\
\text { Baseline at 80\% } \\
\text { Probability (Basche 2000) }\end{array}$ \\
\hline Delivery of first LAW batch initiated & $2 / 2006$ & $7 / 2005$ \\
\hline Delivery of first HLW batch initiated & $8 / 2006$ & $5 / 2006$ \\
\hline ILAW storage available & $12 / 2007$ & $10 / 2007$ \\
\hline IHLW storage available & $9 / 2009$ & $9 / 2008$ \\
\hline HLW $=$ high-level waste & LAW = low-activity waste. \\
IHLW $=$ immobilized high-level waste. \\
ILAW $=$ immobilized low-activity waste.
\end{tabular}




\section{RPP-6118 REV 0}

\subsubsection{Staffing Plan and Analysis}

The Human Resources Staffing Plan for the Tank Farm Contractor, RPP-61 14 (Bosley 2000), evaluates the staffing needs for CHG and its subcontractors as well as listing the staffing needs of Fluor Hanford, Inc. (FH), and BNFL. A summary of the baseline staffing need for the first nine years is shown in Table 3-5 to address construction and operating staff needs through the construction and hot commissioning of the RPP Phase 1 Mission.

Table 3-5. CH2M HILL Hanford Group, Inc.; Fluor Hanford, Inc.; and Privatization Contractor Staffing Profile Summary.

\begin{tabular}{|c|c|c|c|c|c|c|c|c|c|}
\hline 1 Description & FY00 & FY01 & $\mathrm{FY} 02$ & FY03 & FYo4 & FY 05 & FY06 & $\mathrm{FY07}$ & FY08 \\
\hline $\begin{array}{l}\text { CHG non-project staff - including FH and } \\
\text { NHC support to RPP }\end{array}$ & 1,634 & 1,599 & 1,660 & 1,559 & 1,402 & 1,215 & 1,177 & 1,282 & 1,405 \\
\hline CHG subcontractor support & 466 & 458 & 496 & 453 & 413 & 479 & 493 & 580 & 413 \\
\hline $\begin{array}{l}\text { CHG feed delivery/storage } \mathrm{A} / \mathrm{E} \\
\text { construction staff }\end{array}$ & 98 & 288 & 613 & 421 & 464 & 408 & 278 & 171 & 135 \\
\hline $\begin{array}{l}\text { CHG operations } \\
\text { delivery/storage c }\end{array}$ & 59 & 79 & 79 & 139 & 159 & 159 & 139 & 95 & 139 \\
\hline CHG Subtotal & 2,257 & 2,424 & 2,848 & 2,572 & 2,438 & 2,261 & 2,087 & 2,128 & 2,092 \\
\hline FH projects staff & 2,164 & 2,292 & 2,244 & 2,160 & 1,757 & 1,625 & 1,625 & 1,625 & 1,625 \\
\hline $\begin{array}{l}\text { Operator, craft, and operating engineer } \\
\text { support for the Privatization Contractor }\end{array}$ & 0 & 0 & 0 & 0 & 0 & 270 & 0 & 0 & 0 \\
\hline $\begin{array}{l}\text { Privatization Contractor operations and } \\
\text { maintenance staff }\end{array}$ & 0 & 50 & 110 & 239 & 551 & 823 & 798 & 692 & 526 \\
\hline Privatization Contractor construction staff & 932 & 2,463 & 3,058 & 3,477 & 1,968 & 931 & 537 & 383 & 252 \\
\hline Totals & 5,353 & 7,229 & 8,260 & 8,448 & 6,714 & 5,910 & 5,047 & 4,828 & 4,495 \\
\hline
\end{tabular}

1. Staffing needs for FY 2004 and beyond may be underestimated; not all Privatization Phase 2 activities have identified staffing needs. Out-year decline in planned activities may make operators available for Phase 2 activities.

2. FH staffing needs for FY 2006 through FY 2008 were not available. CHG assumed that FH staffing needs for FY 2006 through FY 2008 would be at same level as FY 2005 staffing needs.

$\mathrm{A} / \mathrm{E}=$ architect/engineer.

$\mathrm{FH}=$ Fluor Hanford, Inc.

$\mathrm{FY} \quad=$ fiscal year.
$\mathrm{CHG}=\mathrm{CH} 2 \mathrm{M}$ HILL Hanford Group, Inc.

RPP = River Protection Project.

$\mathrm{NHC}=$ Numatec Hanford Company.

CHG identified four staff skill areas that will experience growth and will be in demand. This growth and demand by competing companies is above their routine recruitment levels, as well as those levels provided through architectural/engineering vendors, local union halls, construction resources from Umatilla Army Depot out-year downsizing, and reduced Washington State construction resulting from passage of Initiative 695. These four skill areas include crafts, engineers, operators, and health physics technicians. Specific recruitment strategies have been developed for each of these areas to ensure that appropriate skills are available to meet mission objectives. 
Based on the evaluation, CHG is confident that it can recruit the required staff to successfully support Phase 1. The identified recruitment strategies are flexible enough to accommodate changes in staff mix and support future changes in the RPP baseline.

It should be noted an increase in staff requirements in FY 2005 for 270 craft, operators, and operating engineers for the Privatization Contractor is in the CHG cost baseline. The data are included in the Staffing Plan to highlight the need for these resources at the Hanford Site. The baseline includes $\$ 26,376,000$ for labor costs associated with hiring and training these individuals. However, the hiring and training of the individuals for these positions is not the contractual responsibility of $\mathrm{CHG}$. Therefore, $\mathrm{CHG}$ requested that $\mathrm{ORP}$ resolve responsibility for hiring and training the staff for these positions through the Integrated Process and Product Development (IPPD)/ICD process "Contract Number DE-AC06-99RL14047, Coordination of Staffing and Training Plans" (Dehn 2000a) See Section 5.1 for further discussion of this hiring and training issue.

\subsection{ABILITY TO SUPPORT ALTERNATIVES OTHER THAN THE BASELINE}

The TFC has consistently demonstrated over the design evolution of the RPP project that it has built flexible plans that can deal with a large variety of feed delivery options, production rates, and delivery schedules. For example, the current RTP baseline strategy has been modified so that waste feed is available from multiple sources in the event a failure occurs in a tank or a farm. Contingency and back up feeds have been identified and scheduled in the baseline. These contingencies provide assurance that feed delivery will not result in idle facility penalties for unused capacity.

The TFC has developed a series of management and analytical tools that are used to support ORP issue evaluations, technical interface issues, project design questions, and support alternative "what if" analyses. These tools include:

- Best Basis Inventory of Tank Contents. This is the authoritative basis to project chemical and radionuclide content of each waste tank. It is updated on a regular basis to incorporate new sampling and operational information.

- Hanford Tank Waste Operations Simulator (HTWOS). This simulator which models chemical characteristics, physical transfers and routing, schedule analysis, and top-level logistics analysis. The simulator and associated special models are the workhorses behind the TFC OUP, the Operational Waste Volume Projections, the Salt Well pumping plan. 


\section{RPP-6118 REV 0}

- Baseline Resource Loaded Critical Path Schedules. The schedules and the associated databases allow evaluation of cost and schedule impacts of various technical alternatives. Depending on the detail required, special planning cases can be developed to assess cost and schedule impacts to support decision making by ORP.

In the last two years, these tools have been used to develop information supporting baseline changes. These ongoing assessments have demonstrated that the TFC can respond to a variety of scenarios. The following are examples of these studies.

- $\quad$ Scenarios Supporting Feed Delivery Planning. More than a dozen alternative feed delivery strategies were modeled using the HTWOS model for the latest revision of the TFC O\&UP. These were variations of three general scenarios:

- Changes in start-up schedules for the Privatization Contractor's Waste Treatment Plant

- Changes in the rate at which the RPP Waste Treatment Plant facilities are able to achieve their maximum sustainable operating rate

- Changes in waste loading in the immobilized glass products.

The results of these analyses were used by ORP to establish planning guidance for the RTP baseline update presented in this document.

- Alternative Generation and Analyses. Alternative generation and analyses studies were performed by the TFC leading to decisions on technical paths forward for the technical baseline. An example of this effort was the Immobilized Low-Activity Waste Disposal Alternatives study and decision to proceed directly with a remote handled trench, rather than using upgraded grout vaults. This change in baseline provided a cost savings of approximately $\$ 250 \mathrm{M}$.

Electrical substation capacity and interface hardware alternatives were evaluated and the project baseline changed to meet Waste Treatment Plant needs efficiently and cost effectively.

- System Optimization Studies Input was provided and results were incorporated into the baseline as directed for these major studies conducted by the Privatization Contractor. Examples of beneficial changes include the elimination of the transfer of a waste tank to the Privatization Contractor and the elimination of cesium and pretreated feed being returned to the TFC for interim storage.

Because TFC has built flexible plans, developed management and analytical tools, and applied these tools to support the design evolution and resulting baseline changes, CHG feels confident in its ability to support alternatives other than the baseline. 
RPP-6118 REV 0

This page intentionally left blank. 


\subsection{MANAGEMENT SYSTEMS}

The management systems include the essential elements of people, processes, tools, and structure that when integrated, form the basis for effective project and product delivery. The processes, tools, and structure as defined in management plans and procedures are addressed in Section 4.1. These processes are described in the context of the organizational structure shown in Figure 4-1.

CHG recognizes the importance of solid planning, policy, and execution documentation to conduct and control of the work. As part of the RTP evaluation process, existing TFC administrative systems and documentation were assessed and, where necessary, improved. CHG management and external consultants played an active role in the production of approved documentation that represented an integrated, comprehensive plan for the tank waste retrieval and disposal mission. Part of this documentation is the assumptions and risks. These are addressed in Section 4.2. In preparation for this declaration of readiness, CHG initiated and participated in a number of reviews to assess status. The review and audit teams provided valuable feedback to the organization for continuous improvement. These reviews are addressed in Section 4.3 .

\subsection{MANAGEMENT PLANS AND PROCEDURES}

The Draft Project Execution Plan for the Tank Farm Contractor, RPP-6017 (Halverson 2000) describes how $\mathrm{CHG}$ executes the contract work scope, and provides guidance to managers, employees, other site supporting contractors and subcontractors on safe and efficient project delivery. The plan provides a mapping to key management policies, plans, and procedures with a focus on project delivery and compliance. The Project Execution Plan includes discussion on planning, work authorization, contract management, acquisition support, requirements management, change control, performance measurement, communications and information management, interface control, risk management and decision management. It also indicates which documents contain additional details of the Project Integrated Baseline and the baseline document hierarchy. The TFC document structure is shown in Figure 4-2.

The Project Execution Plan provides the structure for implementing the requirements that will be identified in the River Protection Project Mission Analysis Report, (ORP 2000a) and the River Protection Project - Project Management Plan DOE/ORP-2000-06 (ORP 2000b). These two documents (both the responsibility of the ORP) were not scheduled to be available for review before this memorandum and the RTP-2 deliverables are submitted. Therefore, the CHG commitment was to prepare a "draft" Project Execution Plan.

The Integrated Environment, Safety, and Health Management System Description for the Tank Farm Contractor (Lake 2000) describes the Integrated Safety Management System (ISMS) used to ensure that safety and quality is integrated into management and work practices at various levels for work performed by $\mathrm{CHG}$ for ORP. This document demonstrates protection of the worker, public, and environmental safety for work supporting the RPP mission. 


\section{RPP-6118 REV 0}

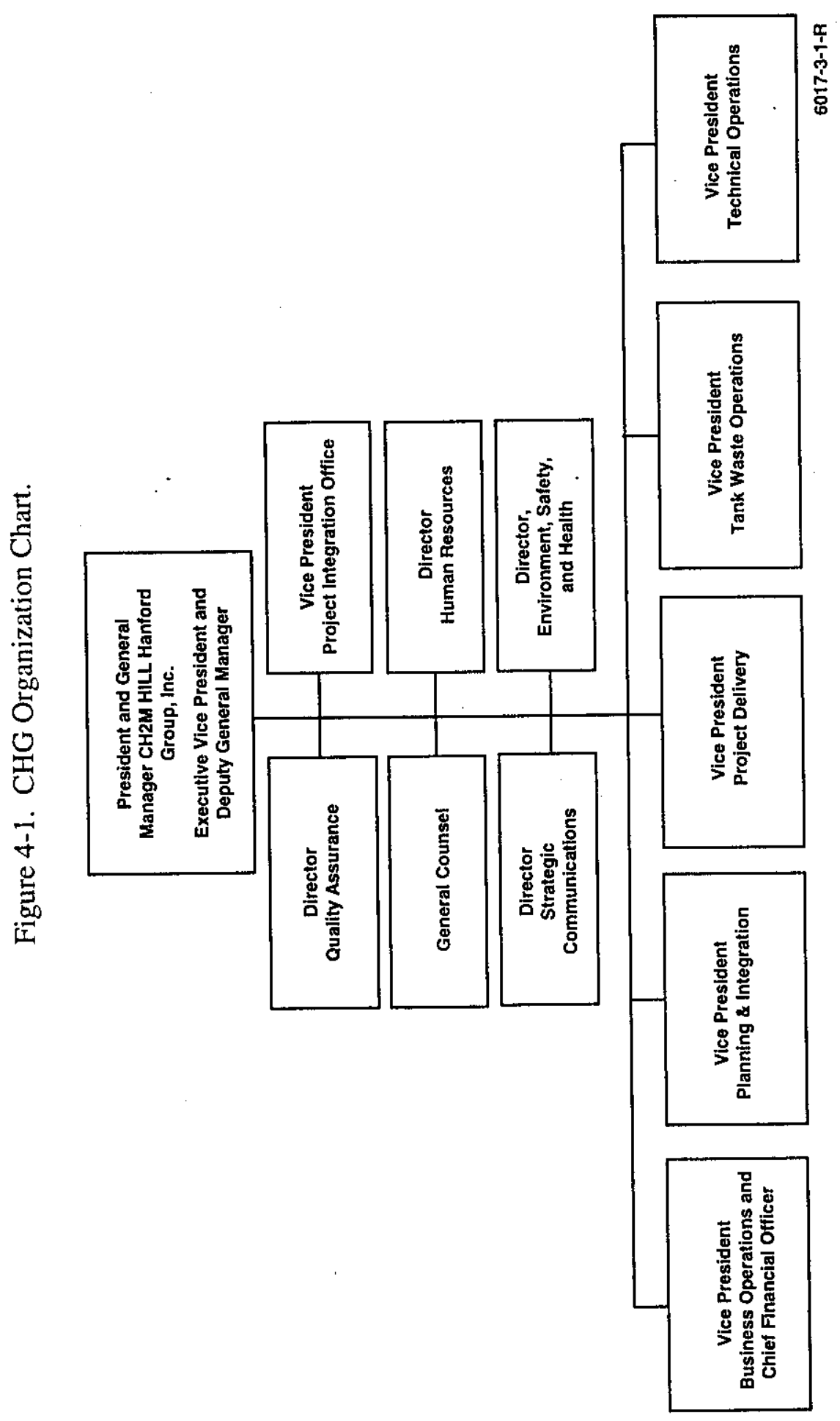




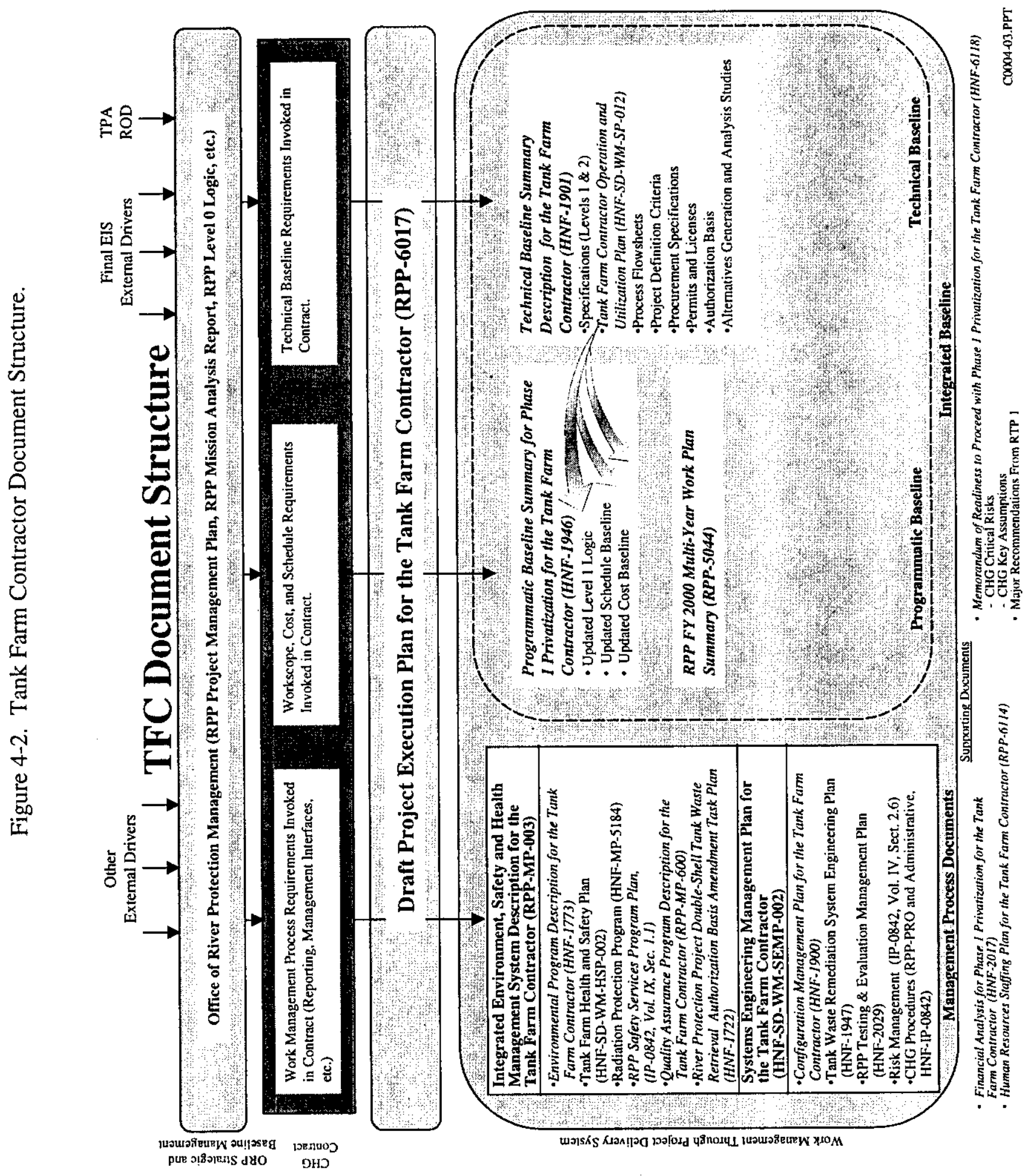




\section{RPP-6118 REV 0}

A number of additional management process, program baseline, and technical baseline documents have been updated or prepared and submitted to ORP for this readiness to proceed. Those documents were listed in Table 1-1.

In addition to the information requested for this declaration, CHG also prepared or upgraded a number of other documents as part of the preparation for this mission. Review of these documents provides additional assurance that administrative systems are ready. Those documents are listed in Table 4-1.

Table 4-1. Other Documents Supporting Readiness to Proceed.

\begin{tabular}{|c|c|}
\hline Document Title & Document No.* \\
\hline $\begin{array}{l}\text { Systems Engineering Management Plan for the Tank Farm } \\
\text { Contractor }\end{array}$ & $\begin{array}{l}\text { HNF-SD-WM-SEMP-002 } \\
\text { (O'Toole 2000) }\end{array}$ \\
\hline $\begin{array}{l}\text { Project Delivery Acquisition and Contracting Plan for the Tank } \\
\text { Farm Contractor }\end{array}$ & $\begin{array}{l}\text { RPP-6113 } \\
\text { (Mercado 2000) }\end{array}$ \\
\hline $\begin{array}{l}\text { River Protection Project Double-Shell Tank Waste Retrieval } \\
\text { Authorization Basis Amendment Task Plan }\end{array}$ & $\begin{array}{l}\text { HNF-1722 } \\
\text { (Harris 2000) }\end{array}$ \\
\hline $\begin{array}{l}\text { Double-Shell Tank Process Waste Sampling Subsystem } \\
\text { Specification }\end{array}$ & $\begin{array}{l}\text { HNF-4154, Rev. } 0 \\
\text { (CHG 2000) }\end{array}$ \\
\hline Double-Shell Tank Monitor and Control Subsystem Specification & $\begin{array}{l}\text { HNF-4155, Rev. } 0 \\
\text { (CHG 2000) }\end{array}$ \\
\hline Double-Shell Tank Utilities Specification & $\begin{array}{l}\text { HNF-4157, Rev. } 0 \\
\text { (CHG 2000) }\end{array}$ \\
\hline $\begin{array}{l}\text { Double-Shell Tank Maintenance and Recovery Subsystem } \\
\text { Definition Report }\end{array}$ & $\begin{array}{l}\text { HNF-4159, Rev. } 0 \\
\text { (CHG 2000) }\end{array}$ \\
\hline Double-Shell Tank Transfer Valving Subsystem Specification & $\begin{array}{l}\text { HNF-4160, Rev. } 0 \\
\text { (CHG 2000) }\end{array}$ \\
\hline Double-Shell Tank Transfer Piping Subsystem Specification & $\begin{array}{l}\text { HNF-4161, Rev. } 0 \\
\text { (CHG 2000) }\end{array}$ \\
\hline Double-Shell Tank Transfer Pump Subsystem & $\begin{array}{l}\text { HNF-4162, Rev. } 0 \\
\text { (CHG 2000) }\end{array}$ \\
\hline Double-Shell Tank Diluent and Flush Subsystem Specification & $\begin{array}{l}\text { HNF-4163, Rev. } 0 \\
\text { (CHG 2000) }\end{array}$ \\
\hline Double-Shell Tank Mixer Pump Subsystem Specification & $\begin{array}{l}\text { HNF-4164, Rev. } 0 \\
\text { (CHG 2000) }\end{array}$ \\
\hline Double-Shell Tank Ventilation Subsystem Specification & $\begin{array}{l}\text { HNF-5196, Rev. } 0 \\
\text { (CHG 2000) }\end{array}$ \\
\hline System Specification for the Double-Shell Tank System & $\begin{array}{l}\text { HNF-SD-WM-TRD-007, } \\
\text { Rev. } 0 \text { (CHG 2000) }\end{array}$ \\
\hline Financial Analysis for Phase 1 for the Tank Farm Contractor & $\begin{array}{l}\text { HNF-2017 } \\
\text { (Basche 2000) }\end{array}$ \\
\hline $\begin{array}{l}\text { Evaluation Criteria to Deliverables Crosswalk for the } \\
\text { Tank Farm Contractor }\end{array}$ & $\begin{array}{l}\text { RPP-6224 } \\
\text { (Kingsbury 2000) }\end{array}$ \\
\hline
\end{tabular}

*Double-Shell Tank Waste Retrieval Specification (CHG 2000) reference citations are presented in a separate table at the end of Section 6.0. 


\subsection{KEY ENABLING ASSUMPTIONS AND CRITICAL RISKS}

\section{CHG Key Enabling Assumptions}

Assumptions are required to enable programmatic planning to proceed in the absence of validated requirements. Planning assumptions are therefore documented as part of the technical or program baseline to support a defensible planning foundation. The CHG key enabling assumptions list (Appendix A) provides the major assumptions that enable planning for tank waste retrieval and disposal mission. The CHG key enabling assumptions come from several sources including:

- Planning guidance provided by the ORP

- Specifications in ORP's contract with the Privatization Contractor for tank waste treatment and immobilization services

- Technical assumptions developed internally by CHG.

\section{CHG Critical Risks}

Risks arise from uncertainties in technical assumptions or performance; estimates of cost and schedule; and changes in programmatic policies, procedures, guidance, and requirements. The consequences of the unplanned event happening (the risk actually comes to pass) can result in cost, schedule, and/or technical performance impacts.

As part of its work planning process, $\mathrm{CHG}$ has identified the critical risks that should be managed to successfully execute its tank waste retrieval and disposal mission for Phase 1 (Appendix B). Critical risks are defined as those risks that are elevated from the work planning, line item project, or program level because one or more or the following conditions are met.

- Risk value is high.

- Consequences are serious.

- Immediate action is required.

- Issue has high visibility/interest from stakeholders or the Federal Government.

- Required mitigation actions are difficult to coordinate.

- Senior management decision is required.

The risk management process is documented in CHG's RPP Administration, HNF-IP-0842, Vol. IV, Sec. 2.6, "Risk Management" (CHG 2000c). 


\section{RPP-6118 REV 0}

\section{Summary of Tank Waste Retrieval and Disposal Mission Risk}

Overall the level of programmatic risk associated with CHG's portion of the RPP mission is acceptable. Mitigating actions for risk have been included in the planning. The level of technical uncertainty is considered to be low because of the following:

1. The required operations and facilities either exist or are well understood.

2. Contingencies have been incorporated into technical operations, e.g., back up tanks have been identified in the event that a primary tank does not meet the feed specification.

3. No technology breakthroughs are required to perform the mission.

4. The technical work is well understood for design, construction, and operations.

5. The technical uncertainties that appear on the list, e.g., mixer pump performance, are manageable.

Schedule delays are the primary source of risk for the tank waste retrieval and disposal mission. For example, Waste Feed Delivery's ability to recover from a pump failure is predicated on how quickly a pump can be replaced and/or whether an alternative waste transfer route or alternative source of tank waste can be used. Management of human resources (e.g., skill mix, sufficient construction forces, key support staff, construction activity interactions with on-going tank farm operations) are another source of potential schedule risk to $\mathrm{CHG}$. The logistical constraints of interaction by multiple construction contractors are addressed in the critical risks CR-013 and CR-066 (Appendix B). Effective recruitment and training programs, coupled with careful work planning and prudent use of key human resources, can effectively mitigate much of the risk associated with these issues (Bosley 2000).

The planning and systems to avoid or mitigate schedule delays are in place, and additional improvements are planned. For example, $\mathrm{CHG}$ 's schedules include schedule contingency; however, this contingency must be managed carefully to maintain the schedule through the key phases of construction and turnover/start up. An in-depth analysis of CHG's schedule risk is provided in HNF-2017 (Basche 2000).

Several of the CHG Critical Risks identified in Appendix B require actions by the ORP and/or the Privatization Contractor to effect an optimal mitigation strategy. Risks that require the attention of ORP in the near future are discussed further in Section 5.1.

CHG will work with the ORP and the Privatization Contractor to develop cost-effective risk mitigation strategies that will further enhance the probability of successfully executing the RPP mission. 


\section{RPP-6118 REV 0}

\subsection{REVIEWS}

A series of reviews have been conducted to assure that CHG's administrative systems are in place to support the mission. The reviews have provided valuable feed back to management for continuous improvement.

\section{ORP Preliminary Review}

DOE ORP has developed a series of criteria review assessment documents (CRADs) based on Life Cycle Asset Management, DOE O 430.1A (DOE 1998) for use in conducting the RTP evaluation. The RTP criteria then were used to evaluate the CHG program planning and technical documentation. Results of that analysis and the CHG follow up actions essential to the Phase 1 RTP decision are shown in Table 4-2.

\section{External Independent Review}

The EIR is being conducted in response to a Congressional mandate that directed DOE to use non-proponent experts to conduct an EIR on all new-start projects whose value is greater than a specified threshold. The purpose of an EIR is to determine objectively whether the scope of the project; its underlying assumptions regarding technology and management; cost and schedule baselines; and contingency provisions are valid and credible within the budgetary constraints under which DOE must operate. The RPP evaluation is being conducted in a two-stage process, Tasks A and B. Task A had three purposes: (1) to assess the readiness of the RPP to undergo detailed review, (2) to develop Lines of Inquiries (LOI) to pursue during Task B, and (3) to develop a plan for Task B. Task B is the detailed Review and Analysis.

Table 4-2. Office of River Protection Criteria Requirements Analysis Document Review Issues and Resolution.

\begin{tabular}{|c|c|c|}
\hline \multicolumn{3}{|c|}{ 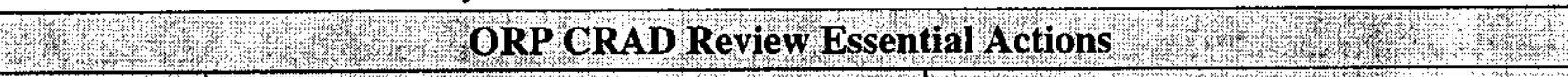 } \\
\hline CRAD & W & W \\
\hline 1.4 & Approve change control procedure & $\begin{array}{l}\text { Complete, HNF-IP-0842, Vol. VIII, } \\
\text { Section 1.1, "Baseline Change } \\
\text { Control" }\end{array}$ \\
\hline 1.4 & Implement change control training plan & $\begin{array}{l}\text { Complete, Web based training } \\
\text { www.rl.gov/twrs/training/ } \\
\text { baselinechange/index.htm }\end{array}$ \\
\hline $3.2 / 7.8$ & $\begin{array}{l}\text { Correct procurement quality assurance } \\
\text { problems }\end{array}$ & $\begin{array}{l}\text { Temporary measures identified and } \\
\text { corrective action plans in place }\end{array}$ \\
\hline 3.7 & $\begin{array}{l}\text { Continue to develop performance profiles } \\
\text { per HNF-3943 (O'Toole and Rossi 1999) }\end{array}$ & $\begin{array}{l}\text { Issue downgraded } \\
\text { Letter CHG-0001661.1 (Wood 2000a) }\end{array}$ \\
\hline 4.8 & Complete staffing plan & Complete, RPP-6114 (Bosley 2000) \\
\hline
\end{tabular}


The Task A conclusion of the EIR Team was that the RPP is ready to undergo Task B, Detailed Review and Analysis.

Lines of Inquiry for Task B have been developed in seven broad areas:

- Project Management

- Business, Finance, Contracting and Capital Finance

- Technical Processes (Vitrification)

- Nuclear Waste Processing

- Nuclear Regulation

- Environmental

- Facilities and Construction.

These LOIs were interpreted as being applicable to CHG. CHG documentation has been identified that addresses the EIR LOI.

\section{CHG Criteria Review Assessment Document Crosswalk}

Guidance and requirements for RTP are extensive, and a comprehensive set of mission documentation has been developed. Key planning products were updated for the RPP RTP and document hierarchy, as shown in Section 1.0 (Table 1-1) and Figure 4-2. As an aid to assure completeness, a crosswalk (RPP-6224, Evaluation Criteria to Deliverables Crosswalk for the Tank Farm Contractor [Kingsbury 2000]) was constructed to link each guidance or requirement item to one or more mission documents. This crosswalk served as a mechanism to assure that all of the CRADs and LOI are being addressed.

\section{Internal Independent Review Team Assessment}

Six independent experts were requested by CHG to assess CHG's RTP. The independent experts were selected based on expertise with the Hanford facilities and the readiness review topics.

This Internal Independent Review Team assessed the CHG readiness in the River Protection Project Readiness-to-Proceed 2 Internal Independent Review Team Final Report, HNF-5835 (Schaus 2000). A summary of their findings stated:

"The Internal Independent Review Team reviewed the Readiness-to-Proceed 2 (RTP-2) documentation, interviewed appropriate CHG personnel, and assessed the status of the construction projects needed to ensure the program's success. The Internal Independent Review Team concluded that CHG has a clear and complete understanding of the work to be accomplished and adequate planning is in place to support Phase 1 of Privatization. CHG has the plans in place to provide the following:

1. The necessary infrastructure support to BNFL

2. The HLW feed to BNFL when it is needed

3. Storage of the immobilized HLW and disposal of the IHLW. 


\section{RPP-6118 REV 0}

The construction projects needed to support Phase 1 are well planned and, with adequate funding, can be in place when needed. The Internal Independent Review Team found some areas of deficiency that CHG management should correct before the RTP-2 memorandum and deliverables are submitted and other areas that, while not crucial to DOE's decision on RTP, are weaknesses that should be corrected in a longer period to improve the overall program."

The deficiencies noted by the review team are listed in Table 4-3. All recommendations for correction prior to RTP-2 have been addressed.

\section{Fluor Hanford, Inc., Readiness Review}

FH evaluated its readiness to support the ORP Phase 1 Part B-2 decision against the CRADs. The FH readiness effort was integrated with that performed by ORP and its contractor's. In preliminary results shared with the TFC, FH found that it was ready to proceed. The assessment identified risks and mitigating actions with particular emphasis on several interface concerns and analytical laboratory funding. These issues are addressed further in Section 5.0.

\section{Other Reviews}

In addition to the items identified above, $\mathrm{CHG}$ considered two other recent relevant reports. The conclusions and recommendations of the recent Audit Report ("Audit Report, The Management of Tank Waste Remediation at the Hanford Site, January 2000 - Holbrook Report, "[DOE 2000]) were considered in the execution of this RTP evaluation as they apply to Phase 1. In Section 5.0 several of the issues brought up in this report regarding integrated life-cycle planning are further discussed.

Table 4-3. Internal Independent Review Team Pre-Readiness-To-Proceed Review. (2 sheets)

\begin{tabular}{|c|l|l|}
\hline CRAD & \multicolumn{1}{|c|}{\begin{tabular}{c}
\multicolumn{1}{|c|}{ Issue } \\
CHG should sign ICDs; consider adding
\end{tabular}} & $\begin{array}{l}\text { Complete } \\
\text { Letter CHG-000125 } \\
\text { (Dehn 2000b) }\end{array}$ \\
\hline 1.0 & $\begin{array}{l}\text { CHG } \\
\text { ICDs to CHG contract; place ICDs under } \\
\text { configuration control }\end{array}$ & $\begin{array}{l}\text { Complete } \\
\text { RPP-6118 }\end{array}$ \\
\hline 1.0 & $\begin{array}{l}\text { Identify plans, policies, procedures, and } \\
\text { directives to revise }\end{array}$ & $\begin{array}{l}\text { Complete } \\
\text { HNF-SD-WM-SEMP-002 }\end{array}$ \\
\hline 3.0 & Update the SEMP & $\begin{array}{l}\text { Complete } \\
\text { RPP-6117 }\end{array}$ \\
\hline
\end{tabular}


Table 4-3. Internal Independent Review Team Pre-Readiness-To-Proceed Review. (2 sheets)

\begin{tabular}{|c|c|c|}
\hline CRAD & Issue & Resolution \\
\hline 3.0 & $\begin{array}{l}\text { Develop action plan for timely issuance of } \\
\text { Level } 1 \text { and Level } 2 \text { specifications }\end{array}$ & $\begin{array}{l}\text { The following specifications have } \\
\text { been prepared: } \\
\text { HNF-4154, HNF-4155, HNF-4157, } \\
\text { HNF-4159, HNF-4160, HNF-4161, } \\
\text { HNF-4162, HNF-4163, HNF-4164, } \\
\text { HNF-5196, } \\
\text { HNF-SD-WM-TRD-007 } \\
\text { (Double-Shell Tank Waste Retrieval } \\
\text { Specifications, CHG 2000) }\end{array}$ \\
\hline 7.0 & $\begin{array}{l}\text { ES\&H Program Plan and Integrated ES\&H } \\
\text { Management System Plan should include all } \\
\text { safety and health programs }\end{array}$ & $\begin{array}{l}\text { Complete } \\
\text { RPP-MP-003 (CHG 2000), } \\
\text { HNF-IP-0842, Vol. IX, Section } 1.1 \\
\text { (CHG 2000e) }\end{array}$ \\
\hline $\begin{array}{l}\text { CHG = } \\
\text { CRAD = } \\
\text { ES\&H = } \\
\text { ICD }=\end{array}$ & $\begin{array}{l}\text { M HILL Hanford Group, Inc. } \\
\text { la review assessment document. } \\
\text { onment, Safety, and Health. } \\
\text { ace Control Document. }\end{array}$ & $\begin{array}{l}\text { Office of River Protection. } \\
\text { readiness to proceed. } \\
\text { Systems Engineering Management Plan. }\end{array}$ \\
\hline
\end{tabular}

The conclusions and recommendations of the recent Office of Science and Technology Tanks Focus Area report, (DOE/EM-0493, "Technical Alternatives to Reduce Risk in the Hanford Tank Waste Remediation System Phase I Privatization Project," September 1999 - Harmon Report) were also considered in the RTP evaluation. The TFC technical and programmatic baselines include technology efforts, such as the mixer pump testing in Tank AZ-101, that were strongly supported by the reviewing team. The baseline support for analytical services is further discussed in Section 5.0. 


\subsection{IDENTIFIED MANAGEMENT ISSUES, DEFICIENCIES AND CORRECTIVE ACTIONS}

During the course of CHG's readiness assessment, a number of issues were identified that require attention to assure that they do not become impediments to achieving success in the tank waste retrieval and disposal mission. Sources included the CRAD and LOI review and the critical risk list. Issues have been identified, and corrective actions are planned where appropriate and included in the updated project baseline. They are grouped to represent the primary party responsible for action. The issues that have identified deficiencies and corrective actions are summarized in Tables 5-1 and 5-2. In each case the issue can be resolved in time to meet the necessary feed delivery and storage and disposal scheduled activities. While some of the indicated dates are before August 2000, none are considered to be necessary to be completed before a decision to proceed.

\subsection{RECOMMENDATIONS AND ACTIONS FOR OFFICE OF RIVER PROTECTION ATTENTION}

Table 5-1 summarizes the list of the recommended improvements and associate corrective actions recommended completion dates.

Table 5-1. Deficiencies and Corrective Actions for the Office of River Protection. (2 sheets)

\begin{tabular}{|c|c|c|}
\hline Deficiency & Correctiye Action & Date \\
\hline 1a. Offstandard feed batches & $\begin{array}{l}\text { Modify feed envelope specifications to } \\
\text { accommodate feeds contained in feed staging plan }\end{array}$ & $\begin{array}{l}\text { Prior to start of } \\
\text { construction of } \\
\text { DST retrieval } \\
\text { systems } \\
\text { (est. } 12 / 2000 \text { ) }\end{array}$ \\
\hline $\begin{array}{l}\text { Ib Analytical differences in feed } \\
\text { certification samples }\end{array}$ & Establish sampling reconciliation process. & $\begin{array}{l}\text { Prior to transfer } \\
\text { of waste to } \\
\text { Privatization } \\
\text { Contractor } \\
\text { facilities } \\
(4 / 2006)\end{array}$ \\
\hline $\begin{array}{l}\text { 1c. Disposition of out-of- } \\
\text { specification feed }\end{array}$ & $\begin{array}{l}\text { Establish a waste disposition reconciliation } \\
\text { process. }\end{array}$ & \\
\hline 2. Informal interfaces & $\begin{array}{l}\text { Require CHG commitment and signatures on all } \\
\text { ICDs and establish CHG contractual relationship } \\
\text { with other site contractors to support the RPP } \\
\text { project }\end{array}$ & $9 / 2000$ \\
\hline $\begin{array}{l}\text { 3. Lack of clarity about } \mathrm{CHG} \\
\text { responsibility for hiring and } \\
\text { training certain BNFL staff }\end{array}$ & $\begin{array}{l}\text { Resolve responsibility for hiring and training the } \\
\text { staff }\end{array}$ & $\begin{array}{l}\text { Prior to contract } \\
\text { being finalized } \\
\text { with } \\
\text { Privatization } \\
\text { Contractor } \\
(8 / 24 / 00)\end{array}$ \\
\hline
\end{tabular}


Table 5-1. Deficiencies and Corrective Actions for the Office of River Protection. (2 sheets)

\begin{tabular}{|c|c|c|}
\hline Deficiency & Corrective Action & Date \\
\hline $\begin{array}{l}\text { 4. Updated RTP baseline does not } \\
\text { address any different, new } \\
\text { WDOE milestones }\end{array}$ & $\begin{array}{l}\text { Reconcile updated RTP baseline with newly } \\
\text { imposed TPA milestones and incorporate into new } \\
\text { guidance to TFC }\end{array}$ & $\begin{array}{l}\text { 6/2000 } \\
\text { (MYWP BUG) }\end{array}$ \\
\hline $\begin{array}{l}\text { 5. Lack of common scheduling } \\
\text { basis for Privatization Contractor } \\
\text { and TFC }\end{array}$ & $\begin{array}{l}\text { Resolve difference in planning guidance to TFC } \\
\text { with Privatization Contractor agreed upon } \\
\text { schedule. }\end{array}$ & $\begin{array}{l}\text { Concurrent with } \\
\text { decision to } \\
\text { proceed with } \\
\text { Phase l B-2 } \\
(8 / 24 / 00)\end{array}$ \\
\hline $\begin{array}{l}\text { 6. Additional sampling } \\
\text { requirements }\end{array}$ & $\begin{array}{l}\text { Identify additional sampling requirements to meet, } \\
\text { LDR, RCRA and safety basis needs }\end{array}$ & $\begin{array}{l}6 / 2000 \\
\text { (MYWP BUG) }\end{array}$ \\
\hline $\begin{array}{l}\text { 7. Inadequate funding for } 222-S \\
\text { Analytical Lab }\end{array}$ & $\begin{array}{l}\text { Work with RL to provide baseline funding to } \\
\text { support needed analytical capability. }\end{array}$ & $\begin{array}{l}\text { 6/ } 2000 \\
\text { (MYWP BUG) }\end{array}$ \\
\hline $\begin{array}{l}\text { 8. Planning basis for the } \\
\text { Privatization Contractor }\end{array}$ & $\begin{array}{l}\text { Privatization Contractor development of } \\
\text { production models and interface data. }\end{array}$ & $\begin{array}{l}\text { Ongoing, } \\
\text { beginning with } \\
\text { next update to } \\
\text { ICDs and } \\
\text { associated } \\
\text { schedules }\end{array}$ \\
\hline $\begin{array}{l}\text { 9. Phase } 2 \text { mission definition key } \\
\text { issues }\end{array}$ & $\begin{array}{l}\text { Develop a defensible, technically based plan for } \\
\text { Phase } 2\end{array}$ & $6 / 2003$ \\
\hline \multicolumn{3}{|c|}{$\begin{aligned} \text { BUG }= & \text { Baseline Update Guidance. } \\
\text { CHG }= & \text { CH2M HILL Hanford Group, Inc. } \\
\text { DST }= & \text { double-shell tank. } \\
\text { ICD }= & \text { interface control document. } \\
\text { LDR }= & \text { land disposal restrictions. } \\
\text { MYWP }= & \text { multi-year work plan. } \\
\text { RCRA }= & \text { Resource Conservation and Recovery Act of } \\
& 1976 .\end{aligned}$} \\
\hline
\end{tabular}

\section{Feed Envelopes and Management of Out-of-Specification Feed Batches}

The planning assumptions specified a waste tank delivery sequence that may limit CHG's ability to meet all applicable feed envelope specifications. CHG has developed a feed staging plan that is projected to meet the majority of the component specifications, but a small number of feed batches are currently projected to exceed the specification for one or more waste constituents. Although the ORP planning assumption directs us to assume that the Privatization Contractor will accept these wastes, $\mathrm{CHG}$ recommends adjustments to the feed envelope specifications. See CHG Critical Risk CR-050 in Appendix B.

The waste feed envelopes were originally developed in 1995, since then, additional sampling and analysis of candidate waste feed tanks has taken place. Considerable random and systematic uncertainty exists in the sampling, analysis, and reconciliation of the various sample results. The analytical results will be obtained by differing techniques at different times by various laboratories in the certification process. CHG recommends that ORP establish, in advance, a 
sampling reconciliation process to deal with analytical differences between various feed certification samples.

While $\mathrm{CHG}$ is planning to deliver material in specification, $\mathrm{CHG}$ believes it is likely that individual components may exceed current feed envelopes in the feed delivery process. An agreed reconciliation process is recommended that bounds ORP's liability for out of specification material. There will be little available tank space to transfer the material back to the TFC. Once the material has been transferred to the Privatization Contractor and it is determined that one or more constituents are outside the feed envelope specification, schedule delays and cost impacts are likely. CHG plans to have only one or two backup feed tanks certified and staged at any point in the schedule.

The feed envelope specification issues should be resolved before start of construction of retrieval systems for the planned feed tanks to avoid changes to the planning sequence for waste feed delivery.

\section{Formalization of Interfaces}

ORP currently manages a defined set of interfaces with the Privatization Contractor through the IPPD process. Technical interfaces are informally managed between CHG, the Privatization Contractor, and Project Hanford team. The management between these interfaces needs to be formalized through changes in the contracts of the various performing parties to assure accountability and cost effectiveness in meeting ORP's requirements. Currently contractual mechanisms exist between ORP and the Privatization Contractor; ORP and CHG; and U.S. Department of Energy, Richland Operations Office (RL) and the Project Hanford team. Assignment of responsibility and accountability for work that $\mathrm{FH}$ performs through $\mathrm{CHG}$ to support the Privatization Contractor is now only coordinated by the IPPD process. See Critical Risk CR-002 in Appendix B.

CHG recommends that (1) ORP modify the IPPD process and require CHG commitment and signatures on ICDs and (2) CHG establish contractual relationships with other site contractors to support the RPP project. These actions should be completed by September 2000 contract documents to establish roles and responsibilities for the remainder of the Phase1 mission.

\section{Provision and Training of the Privatization Contractor Operators and Staff}

The schedule for the planning case (Diediker, 2000) includes an increase in staff requirements in FY 2005 for 270 craft, operators, and operating engineers in the CHG funding baseline. The staff to support these actions is for the Privatization Contractor. The data are included in the Staffing Plan to highlight the need for these resources at the Hanford Site and to acknowledge the $\$ 26,376,000$ included in the baseline for labor costs associated with hiring and training these individuals. Hiring and training of the individuals for these positions are not the contractual responsibilities of $\mathrm{CHG}$.

CHG has requested that ORP resolve responsibility for hiring and training the staff for these positions through the IPPD/ICD process (Dehn, 2000a). CHG recommends that this reconciliation be resolved prior to finalizing contract arrangements with the Privatization Contractor. 


\section{Washington State Department of Ecology Imposed Milestones (Interim and Final)}

The Washington State Department of Ecology (WDOE) has recently imposed a series of retrieval, treatment, storage and disposal milestones (Fitzsimmons and Clarke 2000) on ORP that are different than the Baseline Summary (Diediker 2000). The Baseline Summary was developed in consonance with the ORP planning assumptions, and does not consider the impact of these imposed milestones.

CHG recommends that ORP evaluate the impact of the WDOE directed milestones on the RPP.

\section{Common Scheduling Basis for the Privatization Contractor and CH2M HILL Hanford Group, Inc.}

The Privatization Contractor's master plan is developed around a "planning case" schedule that initiates hot operations as early as 2005. ORP direction to the TFC is planning to the

Privatization Contractor " $90 \%$ trend planning case" schedule, with hot commissioning in 2006. CHG recommends that ORP resolve these planning differences. If the Privatization Contractor is successful in achieving this acceleration, the TFC needs to revise its plans to successfully meet the accelerated feed delivery and immobilized waste storage requirements.

When ORP finalizes its decision to proceed with the Privatization Contractor, CHG recommends that direction should be given to the TFC to match a schedule defined in the Privatization Contractor's contract.

\section{Ability of the Privatization Contractor to Reach Agreement with Ecology and DOE Regulatory Unit on the Characterization Program Needed to Meet LDR, RCRA and Safety Basis Requirements}

The ongoing Privatization Contractor negotiations with Ecology and the DOE Regulatory Unit may establish additional sampling requirements that must be met by the TFC. This could have a significant cost impact and may also become part of the 222-S analytical laboratory funding issue discussed below.

CHG recommends that ORP resolve these negotiations prior to the FY 2001 MYWP update, so that detailed costs and plans can be included in the TFC baseline.

\section{Base Funding Requirements to Support 222-S Analytical Laboratory}

FH manages the 222-S Analytical Laboratory. The laboratory receives funding from the site service pools for base operations and upgrades and incremental funding based on actual sample volume. FH has identified an issue with adequate funding for minimum staffing levels, along with funding for needed upgrades. CHG has included $\$ 8.8 \mathrm{M}$ in the updated RTP baseline to support laboratory upgrades. This may help solve part of the problem but additional resolution of the base staffing level is required. See Critical Risk CR-032 in Appendix B.

CHG recommends that ORP work with RL to establish a workable funding strategy that meets the baseline requirements for analytical services at a reasonable cost. Upgrade requirements to maintain the physical capability also must be provided. $\mathrm{CHG}$ recommends that this coordination be completed before the FY 2001 multi-year program plan planning cycle for RL and ORP. 


\section{RPP-6118 REV 0}

\section{Planning Basis for the Privatization Contractor Interfaces}

ORP planning guidance provides CHG with a series of schedule and process efficiency assumptions and requires the TFC to estimate performance of the Privatization Contractor facilities to establish planning baselines. The Privatization Contractor has completed preliminary design, and CHG has helped the Privatization Contractor build a production modeling capability. It is more appropriate for the Privatization Contractor to define feed and product interfaces. CHG expects that feed delivery interfaces should be defined as amounts of feed envelopes required on a given date. Immobilized product storage and disposal should be defined as numbers of canisters to be transported as a function of time. This would be supplemented by the necessary design parameters such as dimensions, weight, radiation levels, etc.

CHG is ready to assist ORP and the Privatization Contractor in developing the necessary product models and information.

\section{Key Technical Issues for Phase 2 Mission Definition}

Life-cycle technical analysis conducted in support of the RTP activities identified key technical issues that should be resolved prior to the initiation of Phase 2 process design activities. Sensitivity analysis indicated that the total HLW glass volume could double if a technical solution for chromium removal during sludge washing is not identified.

To meet the ORP guidance planning rates for Phase 2 vitrification capacity, the Tank Farm Contractor Operation and Utilization Plan (Kirkbride 2000) assumed that up to seven SSTs could be retrieved concurrently, with up to two SSTs retrievals operating concurrently in a given tank farm. This is substantially higher than the TFC believed reasonable in HNF-2021, Management Assessment of Tank Waste Remediation System Contractor Readiness to Proceed with Phase 1B Privatization (Payne et al 1998).

As identified in the IG-30 audit (DOE 2000), ORP has not developed a defensible, technically based plan for Phase 2 retrieval, treatment, and disposal. With the completion of 241-C-106 sluicing, the completion of waste retrieval activities at the Oak Ridge National Laboratory, retrieval and immobilization mission nearly complete at West Valley, New York, and extended operation of the Defense Waste Processing Facility at the Savannah River Plant, much real operating and cost data are now available that were not available when the current Phase 2 life-cycle costs were prepared.

CHG recommends that an effort be initiated to gather and organize the new information that is available, use the HTWOS and Project Integration Office life-cycle models, conduct selective technology demonstrations, and develop a technically defensible proposal for Phase 2 . This would be a logical extension from the Privatization Contractor proposal and would improve the credibility for the strategy articulated in the ORP Strategic Plan.

CHG recommends that the development of a credible Phase 2 plan should be completed in the next three years to build a basis for the Phase 2 decisions, the upcoming tank closure Environmental Impact Statement, and ongoing negotiations with Washington State Department of Ecology. This would facilitate negotiation of program milestones for completion of the mission. 


\section{RPP-6118 REV 0}

\subsection{ISSUES FOR CH2M HILL HANFORD GROUP, INC. TO RESOLVE}

Table 5-2 summarizes the list of the manageable deficiencies and associated corrective actions with dates where the TFC has the action.

Table 5-2. Manageable Deficiencies and Associated Corrective Actions.

\begin{tabular}{|l|l|l|}
\hline \multicolumn{1}{|c|}{ Deficiency } & \multicolumn{1}{|c|}{ Corrective Action } & Date \\
\hline $\begin{array}{l}\text { 1. Breakdown of Quality } \\
\text { Management }\end{array}$ & Corrective Action Plans in place & Complete \\
\hline $\begin{array}{l}\text { 2. Incomplete implementation of } \\
\text { a risk management system }\end{array}$ & Develop risk management plan & $12 / 00$ \\
\hline $\begin{array}{l}\text { 3. Deficiencies in the assessment } \\
\text { of integrity of the DSTs }\end{array}$ & Establish a life-cycle tank integrity program & $\begin{array}{l}9 / 00 \\
\text { (incorporating } \\
\text { ORP MYWP } \\
\text { BUG) }\end{array}$ \\
\hline $\begin{array}{l}\text { 4. Incomplete Design } \\
\text { Specifications for Ongoing } \\
\text { Construction }\end{array}$ & Reconcile engineering work with active projects. & CY 2000 \\
\hline $\begin{array}{l}\text { 5. ORP, Privatization Contractor, } \\
\text { and TFC document and data } \\
\text { consistency }\end{array}$ & $\begin{array}{l}\text { Gap analysis and } \\
\text { Resolve important document inconsistencies }\end{array}$ & $\begin{array}{l}\text { 5/00 } \\
8 / 00 \\
\text { (Privatization } \\
\text { Contractor } \\
\text { authorization to } \\
\text { proceed) }\end{array}$ \\
\hline $\begin{array}{l}\text { 6. Sole source construction } \\
\text { management }\end{array}$ & $\begin{array}{l}\text { Pursue a range of construction managers and } \\
\text { contract mechanisms }\end{array}$ & \begin{tabular}{l} 
FY 2001 \\
\hline
\end{tabular}
\end{tabular}

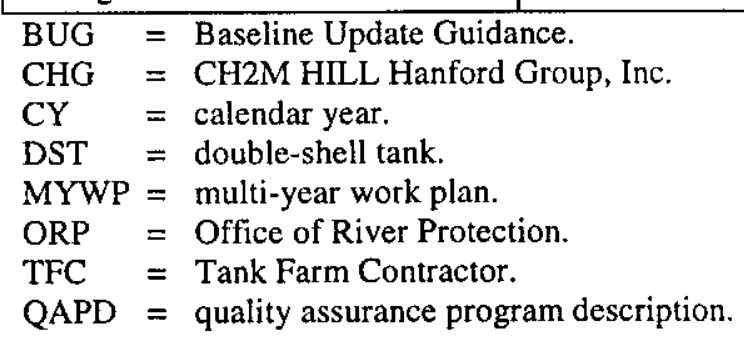

\section{Breakdown of Quality Management}

Recently CHG identified a quality management issue associated with a construction supplier for the W-314 Tank Farm Upgrade Project. CHG identified this as a potential breakdown of the desired management process required in the CHG quality assurance program policy. Construction work on Safety Class equipment was suspended and an aggressive corrective action plan was developed. A Quality Assurance Director reporting to the president was appointed. Responsibilities were clarified and the organization is being trained on the lessons learned. Relationships between site contractors and other subcontract suppliers were reviewed and modifications were made to the quality requirements. 
The corrective actions that came from the independent investigation recommendations, the corrective action plan, and the W-314 Transfer Pipe Procurement event include improvements in construction management, procurement, and quality assurance program. Temporary measures have been identified and corrective action plans are in place.

\section{Implementation of Risk Management}

The CHG Risk Management Procedure describes the process of risk identification, analysis, and mitigation. Through this process, technical and programmatic risks are communicated to decision-makers so that actions can be taken to ensure program success. It requires that technical documents be reviewed as part of the risk identification process and that identified risks be recorded in the TBRs and have planned mitigation activities. It uses Monte Carlo simulation to assist with the cost risk analysis and schedule risk analysis.

Analysis results are provided to the project planners to support development and change management of the TBRs. Risk lists are generated at the TBR level. A Critical Risk List is also generated at the PBS level, using information from the lower tier lists as well as from other management layers. Mitigation actions are included in the TBRs and MYWPs, assigned to responsible individuals and tracked to closure.

The CHG Contract was effective on October 1, 1999, and requires the contractor to have a Risk Management Plan. The previous contractor, while a subcontractor to FDH, decided that a separate risk management plan was no longer necessary. The procedure, HNF-IP-0842, Vol. IV, Sec. 2.6, "Risk Management" (CHG 2000c), along with references in the Systems Engineering Management Plan for the Tank Farm Contractor, HNF-SD-WM-SEMP-002 (O'Toole 2000), served the purpose of a plan.

The TFC will develop an updated Risk Management Plan that fully addresses the requirements of the contract, and will update the risk management procedure to implement any modified requirements. This is planned to be completed by December 2000.

\section{Double-Shell Tank Integrity Issues}

The Department of Ecology has notified RPP that it intends to initiate enforcement action regarding deficiencies in the assessment of integrity of the DSTs. ORP and CHG have developed a proposed resolution plan that would establish a life-cycle tank integrity program that recognizes the value of the DST asset in executing the RPP mission ("Notice of Intent [NOI] to Take Formal Enforcement Action Resulting from Violation of Article VII within the Hanford Federal Facility Agreement and Consent Order, or Tri-Party Agreement," French and Klein 2000). Some of this proposed work is not currently included in the ORP FY 2000 MYWP. If this proposal is accepted and CHG is directed to incorporate this work into the MYWP baseline, it is predicted that minor adjustments to outyear budgets and operating and construction plans may need to be made. These adjustments are not anticipated to have an impact on feed delivery.

The necessary timing on the resolution of this issue remains open pending agreement between DOE/ORP and the State of Washington on a constructive path forward. 


\section{RPP-6118 REV 0}

\section{Status of Project Design Specifications and Ongoing Construction}

The Level 1 and Level 2 requirement specifications include technical elements that remain to be finalized. Feed delivery projects are proceeding at some risk, that subsequent engineering and design work may result in rework of some project designs, procurement, and construction. The TFC is proceeding with a conservative design approach and has accepted the risk, based on the feed delivery schedule.

The engineering work to support reconciliation with the active projects and finalization of the requirement baseline is included in the Baseline Summary (Diediker 2000). The TFC expects to complete comparison with project design activities and necessary reconciliation planning by December 2000.

\section{ORP and TFC Document and Data Consistency}

ORP and the TFC are updating technical plans, resource-loaded schedules, management systems, and definition of interfaces in parallel for delivery by April 24, 2000. As a result it is anticipated that differences will exist in the plans, documents, and procedures on that date.

An action plan will be developed during the month of May to identify the key disconnects and to initiate planning to bring the various plans, documents, and procedures into agreement.

The TFC will develop a schedule that maximizes the use of normally scheduled updates and revisions to reduce implementation costs, and to allow evaluation of more efficient and effective ways to conduct the TFC business. Important document inconsistencies will be resolved prior to the Privatization Contractor authorization to proceed in August 2000.

\section{Sole Source Construction Management}

At the current time, $\mathrm{CHG}$ has a sole source relationship with Fluor Federal Services for construction management. The RTP baseline (Diediker 2000) includes approximately $\$ 800 \mathrm{M}$ worth of design and construction activity prior to hot operations of the Waste Treatment Plant. While most elements of the design and construction performance chain have several alternative choices for performance, construction management represents a single point failure. A management or subcontractor problem that stalls procurement of field construction on one project by the sole construction manager could result in a delay for the entire program. For example, a quality procurement issue could require shutdown of all procurement on all projects until the issue is resolved. This represents a risk for execution of the RTP baseline.

CHG should pursue the consideration of a range of construction management performers and contract mechanisms. While this will help alleviate the single point failure discussed above, it could also improve competition between the performers and result in cost and schedule savings. Alternatives should be in place during FY 2001. 


\subsection{REFERENCES}

Barrett, M. K., 2000, "Contract No. DE-AC06-99RL14047 - River Protect Project (RPP) Key Enabling Assumptions," (letter 00-PGO-002 to M. P. DeLozier, CH2M HILL Hanford Group, Inc., April 10), U.S. Department of Energy, Office of River Protection, Richland, Washington.

Basche, A. D., 2000, Financial Analysis for Phase 1 Privatization for the Tank Farm Contractor, HNF-2017, Rev. 2, CH2M HILL Hanford Group, Inc., Richland, Washington.

Borneman, L. E., 1998, "Contract Number DE-AC06-96RL13200; Tank Waste Remediation System Privatization - Project Hanford Management Contract Declaration Of Readiness To Proceed With Phase 1B, Tank Waste Remediation System Privatization (Performance Agreement TWR2. 4.2)" (letter FDH-9757162A R2 to W. J. Taylor, U.S. Department of Energy, Richland Operations Office, January 12) Fluor Daniel Hanford, Inc., Richland, Washington.

Bosley, J. W., 2000, Human Resources Staffing Plan for the Tank Farm Contractor, RPP-6114, Rev. 0, CH2M HILL Hanford Group, Inc., Richland, Washington.

CHG, 2000a, Health and Safety Plan for the Tank Farm Contractor, HNF-SD-WM-HSP-002, CH2M HILL Hanford Group, Inc., Richland, Washington.

CHG, 2000b, Integrated Environment, Safety and Health Management System Description for the Tank Farm Contractor, HNF-MP-003, CH2M HILL Hanford Group, Inc., Richland, Washington.

CHG, 2000c, RPP Administration, HNF-IP-0842, Vol. IV, Sec. 2.6, "Risk Management," CH2M HILL Hanford Group, Inc., Richland, Washington.

CHG, 2000d, RPP Administration, HNF-IP-0842, Vol. VII, Sec. 1.1, "Baseline Change Control," CH2M HILL Hanford Group, Inc., Richland, Washington.

CHG, 2000e, RPP Administration, HNF-IP-0842, Vol. IX, Sec. 1.1, "Health and Safety Program Description," CH2M HILL Hanford Group, Inc., Richland, Washington.

Dehn, W. T., 2000a, "Contract Number DE-AC06-99RL14047; Coordination of Staffing and Training Plans," (letter CHG-0001479 to R. T. French, U.S. Department of Energy, Office of River Protection, March 27) CHWM HILL Hanford Group, Inc., Richland, Washington.

Dehn, W. T., 2000b, "Contract Number DE-AC06-99RL14047; Interface Control Agreements," (letter CHG-0001235 to R. T. French, U.S. Department of Energy, Office of River Protection, March 27) CHWM HILL Hanford Group, Inc., Richland, Washington.

Diediker, J. A., 2000, Programmatic Baseline Summary for Phase I Privatization for the Tank Farm Contractor, HNF-1946, Rev. 2, CH2M HILL Hanford Group, Inc., Richland, Washington. 
DOE O 430.1A, 1998, Life Cycle Asset Management, U.S. Department of Energy, Washington, D.C.

DOE, 1996, Critical Decision Criteria, Life Cycle Asset Management, Good Practice Guide, GPG-FM-002, U.S. Department of Energy, Washington, D.C.

DOE, 1999, Technical Alternatives to Reduce Risk in the Hanford Waste Remediation System Phase I Privatization Project, DOE/EM-0493, U.S. Department of Energy, Office of Environmental Management, Washington, D.C.

DOE, 2000, The Management of Tank Waste Remediation at the Hanford Site, January 2000 Holbrook Report, DOE/IG-0456, U.S. Department of Energy, Washington, D.C.

Drawing No. TWR-2086, Rev. 2, River Protection Project Level-O Logic (2000)

Fitzsimmons, T. and C. Clarke (U.S. Environmental Protection Agency), 2000, "Final Determination pursuant to the Hanford Federal Facility Agreement and Consent Order (HFFACO) in the matter of Hanford site high-level radioactive tank waste treatment capacity acquisition, tank waste treatment and associated tank waste work requirements," (to C. Huntoon, Office of Environmental Management; R. T. French, U.S. Department of Energy, Office of River Protection; and K. A. Klein, U.S. Department of Energy, Richland Operations Office), State of Washington Department of Ecology, Olympia, Washington.

French, R. T., 2000, "Contract No. DE-AC06-99RL14047 - Modification to Feed Delivery Sequence," (letter 00-OPD-013 to M. P. DeLozier, CH2M HILL Hanford Group, Inc., January 26) U.S. Department of Energy, Office of River Protection, Richland, Washington. (RLR, 04/20/00)

French, R. T., and K. A. Klein, 2000, "Notice of Intent (NOI) to Take Formal Enforcement Action Resulting from Violation of Article VII within the Hanford Federal Facility Agreement and Consent Order, or Tri-Party Agreement," (letter DOE-RL: 00-ORP-024 to M. A. Wilson, State of Washington Department of Ecology), U.S. Department of Energy, Office of River Protection, and U.S. Department of Energy, Richland Operations Office, Richland, Washington.

Halverson, T. G., 2000, Draft Project Execution Plan for the Tank Farm Contractor, RPP-6017, Rev. 0, CH2M HILL Hanford Group, Inc., Richland, Washington.

Harris, J. P. III, 2000, River Protection Project Double-Shell Tank Waste Retrieval Authorization Basis Amendment Task Plan, HNF-1722, Rev. 2, CH2M HILL Hanford Group, Inc., Richland, Washington.

Hebdon, J. B., 2000, Quality Assurance Program Description for the Tank Farm Contractor, RPP-MP-600, Rev. 0, CH2M HILL Hanford Group, Inc., Richland, Washington.

Honeyman, J. O., and J. A. Voogd, 2000, Memorandum of Readiness to Proceed with Phase 1 Privatization for the Tank Farm Contractor, RPP-6118, Rev. 0, CH2M HILL Hanford Group, Inc., Richland, Washington. 
Kingsbury, R. L., 2000, Evaluation Criteria to Deliverables Crosswalk for the Tank Farm Contractor, RPP-6224, Rev. 0, CH2M HIL Hanford Group, Inc., Richland, Washington. (RLR, 04/19/00)

Kirkbride, R. A., 2000, Tank Farm Contractor Operation and Utilization Plan, HNF-SD-WM-SP-012, Rev. 2, CH2M HILL Hanford Group, Inc., Richland, Washington.

Lake, N. D., 2000, Integrated Environment, Safety, and Health Management System Description for the Tank Farm Contractor, RPP-MP-003, Rev. 1, CH2M HILL Hanford, Group, Inc., Richland, Washington.

LMHC, 1999, River Protection Project FY 2000 Multi-Year Work Plan Summary, RPP-5044, Rev. 0, Lockheed Martin Hanford Corporation, Richland, Washington.

Mercado, L. C., 2000, Project Delivery Acquisition and Contracting Plan for the Tank Farm Contractor, RPP-6113, Rev. 0, CH2M HILL Hanford Group, Inc., Richland, Washington.

O'Toole, S. M., 2000, Systems Engineering Management Plan for the Tank Farm Contractor, HNF-SD-WM-SEMP-002, Rev. 2, CH2M HILL Hanford Group, Inc., Richland, Washington.

O'Toole, S. M., and H. Rossi, 1999, River Protection Project Waste Feed Delivery Program Technical Performance Measurement Assessment Plan, Lockheed Martin Hanford Corporation, Richland, Washington.

ORP, 1999, CH2M HILL Hanford Group, Inc., Contract No. DE-AC06-99RL14047,

U.S. Department of Energy, Office of River Protection, Richland, Washington.

ORP, 2000a, River Protection Project Mission Analysis Report, DOE/ORP-2000-10, Rev. 0, U.S. Department of Energy, Office of River Protection, Richland, Washington.

ORP, 2000b, River Protection Project - Project Management Plan, DOE/ORP-2000-06, Rev. 0, U.S. Department of Energy, Office of River Protection, Richland, Washington.

Payne, M. A., J. O., Honeyman, J. G. Kristofzski, W. T. Thompson, and P. J. Certa, 1998, Management Assessment of Tank Waste Remediation System Contractor Readiness to Proceed With Phase 1B Privatization, HNF-2021, Rev. 0, Lockheed Martin Hanford Corporation, for Fluor Daniel Hanford Inc., Richland, Washington.

Powell, P. A., 2000, Environmental Program Description for the Tank Farm Contractor, HNF-1773, Rev. 3, CH2M HILL Hanford Group, Inc., Richland, Washington.

Schaus, P. S., 1998, Tank Waste Remediation System Retrieval and Disposal Mission Readinessto-Proceed Responses to Internal Independent Assessment, HNF-2018, Rev. 0, Lockheed Martin Hanford Corporation, Richland, Washington. 
Schaus, P. S., 2000, River Protection Project Readiness-to-Proceed 2 Internal Independent Review Team Final Report, HNF-5835, Rev. 1, CH2M HILL Hanford Group, Inc., Richland, Washington.

Short, J. J., II, 2000, "Contract No. DE-AC06-99RL14047 - The U.S. Department of Energy, Office of River Protection (ORP) Mission Planning Guidance for Fiscal Year (FY) 2002 - Revision 1," (letter 00-MSO-009 to M. P. DeLozier, CH2M HILL Hanford Group, Inc., February 3), U.S. Department of Energy, Office of River Protection, Richland, Washington.

Taylor, W. J., 1998, “Contract Number DE-AC06-96RL13200 - Evaluation of Tank Waste Remediation System (TWRS) Readiness to Proceed (RTP) With Privatization Phase 1B," (letter 98-WDD-032, to H. J. Hatch, President, Fluor Daniel Hanford, Inc., March 16) U.S. Department of Energy, Richland Operations Office, Richland, Washington.

Tedeschi, A. R., 2000, Technical Baseline Summary Description for the Tank Farm Contractor, HNF-1901, Rev. 2, CH2M HILL Hanford Group, Inc., Richland, Washington.

Weir, W. R., 2000, Configuration Management Plan for the Tank Farm Contractor, HNF-1900, Rev. 1, CH2M HILL Hanford Group Inc., Richland, Washington.

Wood, R. F., 2000a, to J. J. Short, DOE-ORP, "Contract No. DE-AC06-99RL14047, Performance Incentive ORP4.5.1, Section 4," "Assumption/Technical Boundary Conditions,"(letter CHG-0001661.1, to J. J. Short, U.S. Department of Energy, Office of River Protection, April 5), CH2M HILL Hanford Group, Inc., Richland, Washington.

Wood, R. F., 2000b, to J. J. Short, DOE-ORP, “Contract No. DE-AC06-99RL14047, River Protection Project Fiscal Year 2000 Performance Incentive ORP 4.5.1, Revision 1," "Phase 1 Part B-2 Readiness to Proceed, Section 3, Standard 3, and Section 4, Standard 2,"(letter CHG-0002228, to J. J. Short, U.S. Department of Energy, Office of River Protection, April 24), CH2M HILL Hanford Group, Inc., Richland, Washington.

\section{Double-Shell Tank Waste Retrieval Level 1 Specification}

CHG, 2000, System Specification for the Double-Shell Tank System, HNF-SD-WM-TRD-007, Rev. 0, Numatec Hanford Corporation for CH2M HILL Hanford Group, Inc., Richland, Washington.

\section{Double-Shell Tank Waste Retrieval Specifications}

CHG, 2000, Double-Shell Tank Diluent and Flush Subsystem Specification, HNF-4163, Rev. 0, Numatec Hanford Corporation for CH2M HILL Hanford Group, Inc., Richland, Washington. 


\section{Double-Shell Tank Waste Retrieval Specifications}

CHG, 2000, Double-Shell Tank Maintenance and Recovery Subsystem Definition Report, HNF-4159, Rev. 0, Numatec Hanford Corporation for CH2M HILL Hanford Group, Inc., Richland, Washington.

CHG, 2000, Double-Shell Tank Mixer Pump Subsystem Specification, HNF-4164, Rev. 0, Numatec Hanford Corporation for CH2M HILL Hanford Group, Inc., Richland, Washington.

CHG, 2000, Double-Shell Tank Monitor and Control Subsystem, HNF-4155, Rev. 0, Numatec Hanford Corporation for CH2M HILL Hanford Group, Inc., Richland, Washington.

CHG, 2000, Double-Shell Tank Process Waste Sampling Subsystem Specification, HNF-4154, Rev. 0, Numatec Hanford Corporation for CH2M HILL Hanford Group, Inc., Richland, Washington.

CHG, 2000, Double-Shell Tank Transfer Piping Subsystem Specification, HNF-4161, Rev. 0, Numatec Hanford Corporation for CH2M HILL Hanford Group, Inc., Richland, Washington.

CHG, 2000, Double-Shell Tank Transfer Pump Subsystem Specification, HNF-4162, Rev. 0, Numatec Hanford Corporation for CH2M HILL Hanford Group, Inc., Richland, Washington.

CHG, 2000, Double-Shell Tank Transfer Valving Subsystem Specification, HNF-4160, Rev. 0, Numatec Hanford Corporation for CH2M HILL Hanford Group, Inc., Richland, Washington.

CHG, 2000, Double-Shell Tank Utilities Specification, HNF-4157, Rev. 0, Numatec Hanford Corporation for CH2M HILL Hanford Group, Inc., Richland, Washington.

CHG, 2000, Double-Shell Tank Ventilation Subsystem Specification, HNF-5196, Rev. 0, Numatec Hanford Corporation for CH2M HILL Hanford Group, Inc., Richland, Washington. 
RPP-6118 REV 0

This page intentionally left blank. 
RPP-6118 REV 0

APPENDIX A

CH2M HILL HANFORD GROUP, INC. KEY ASSUMPTIONS

A-i 
RPP-6118 REV 0

This page intentionally left blank.

A-ii 


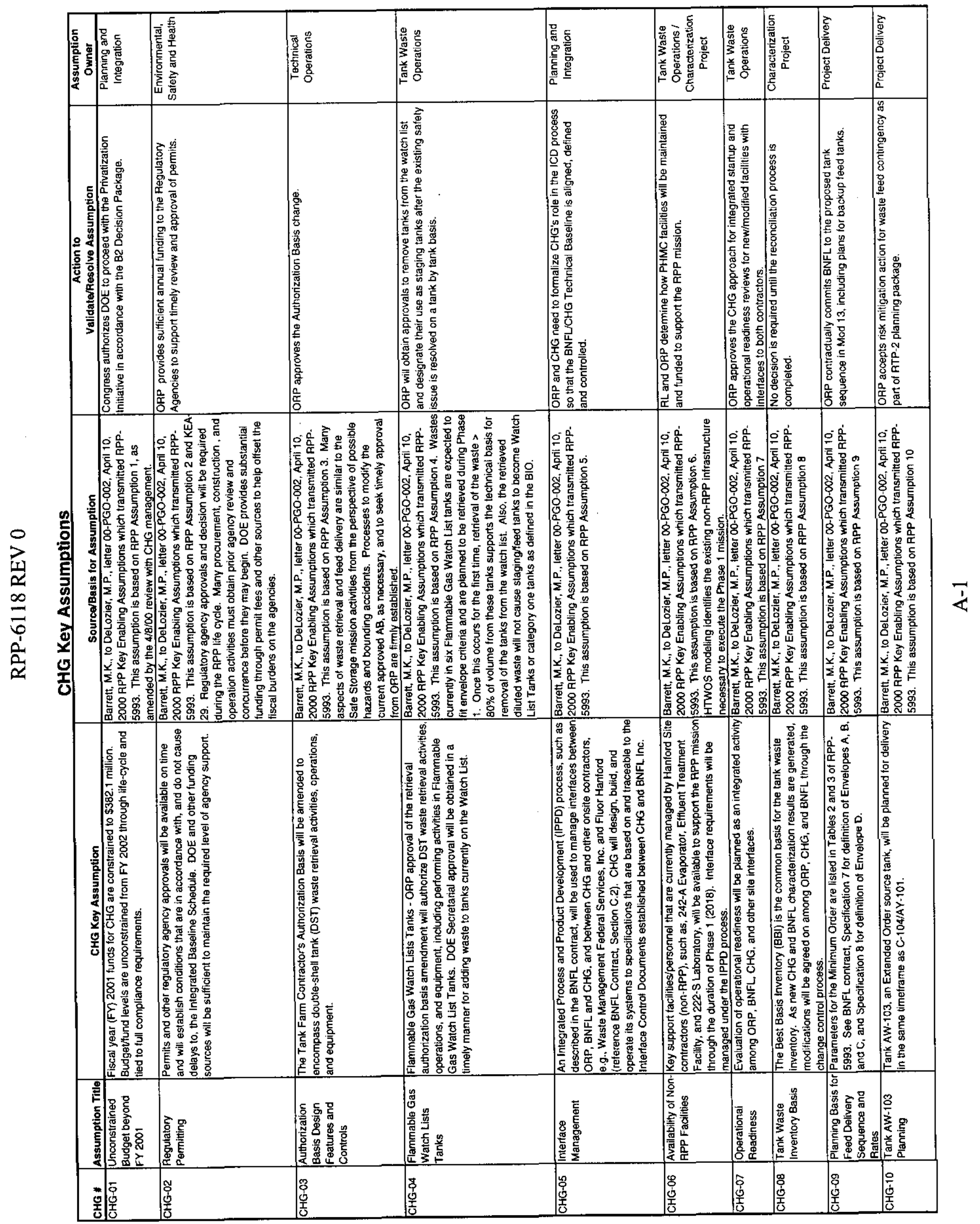




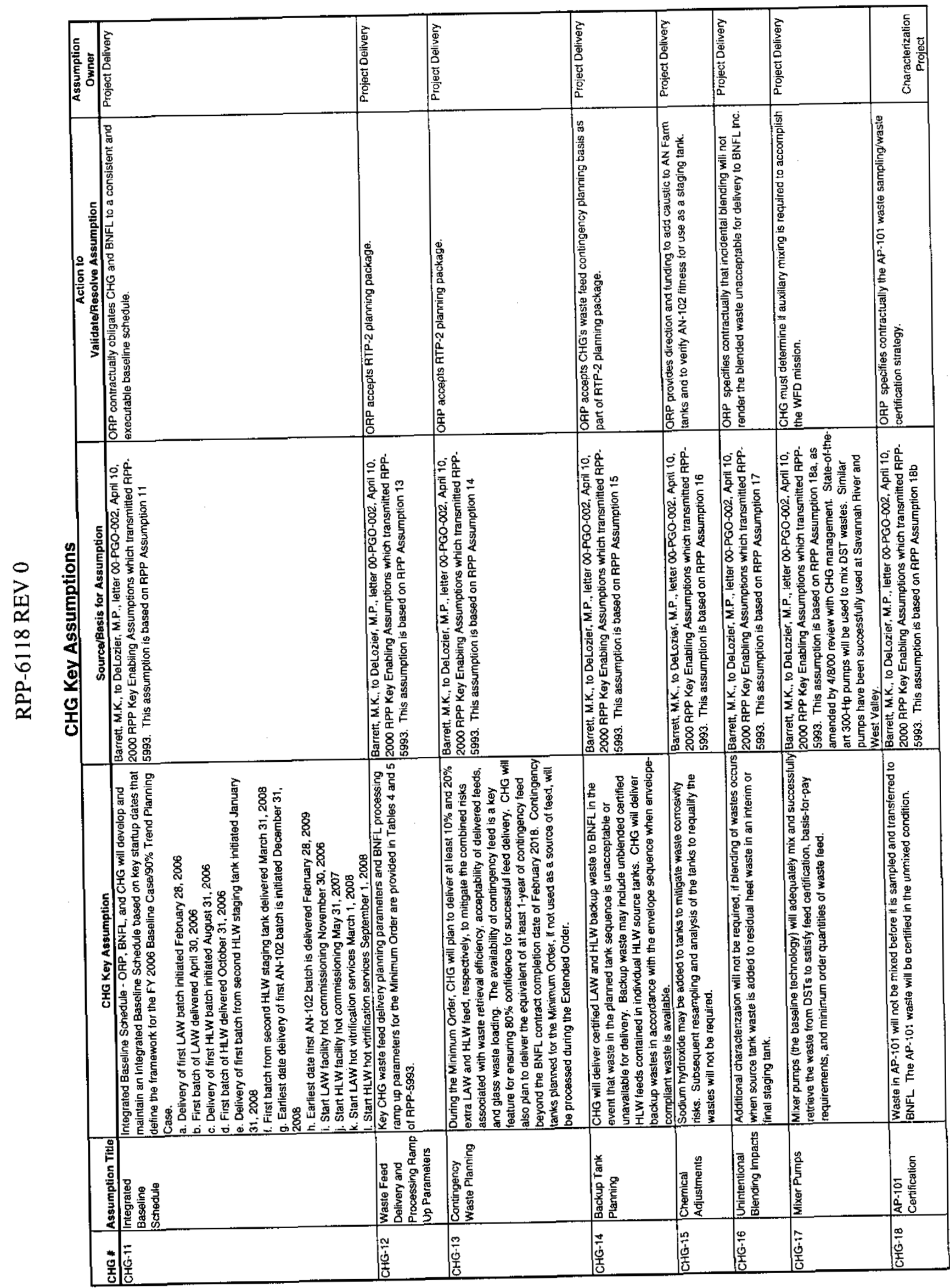

4 


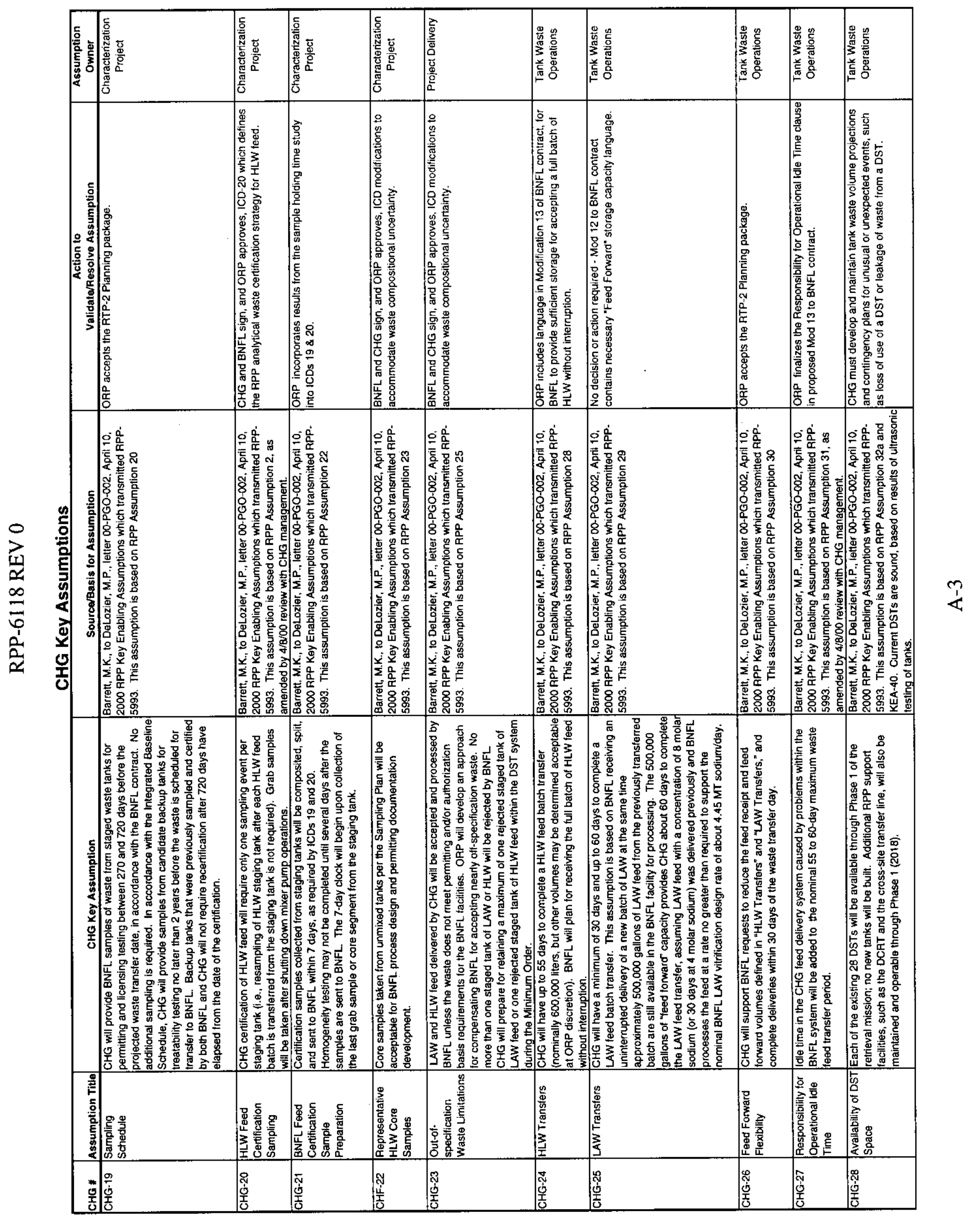




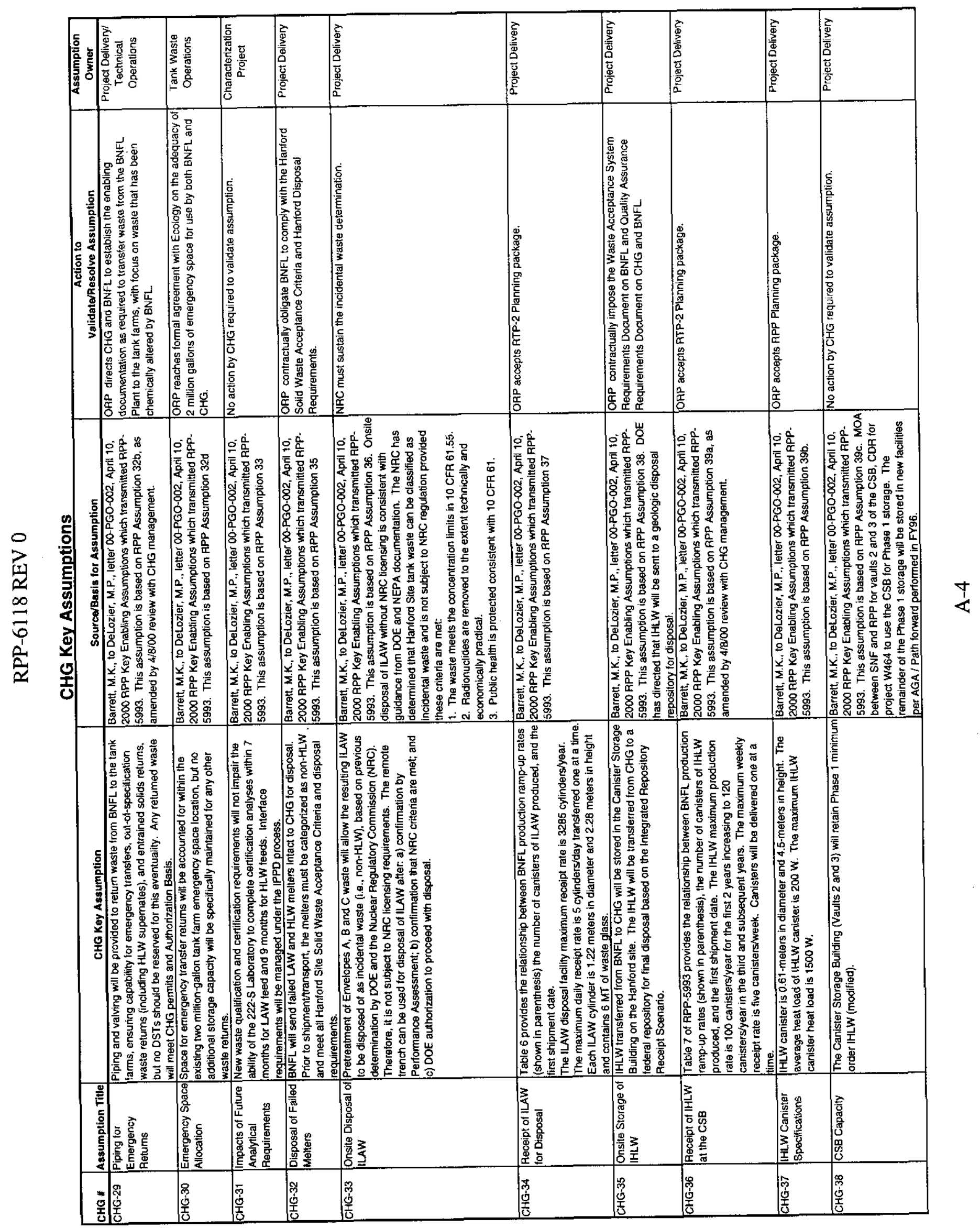




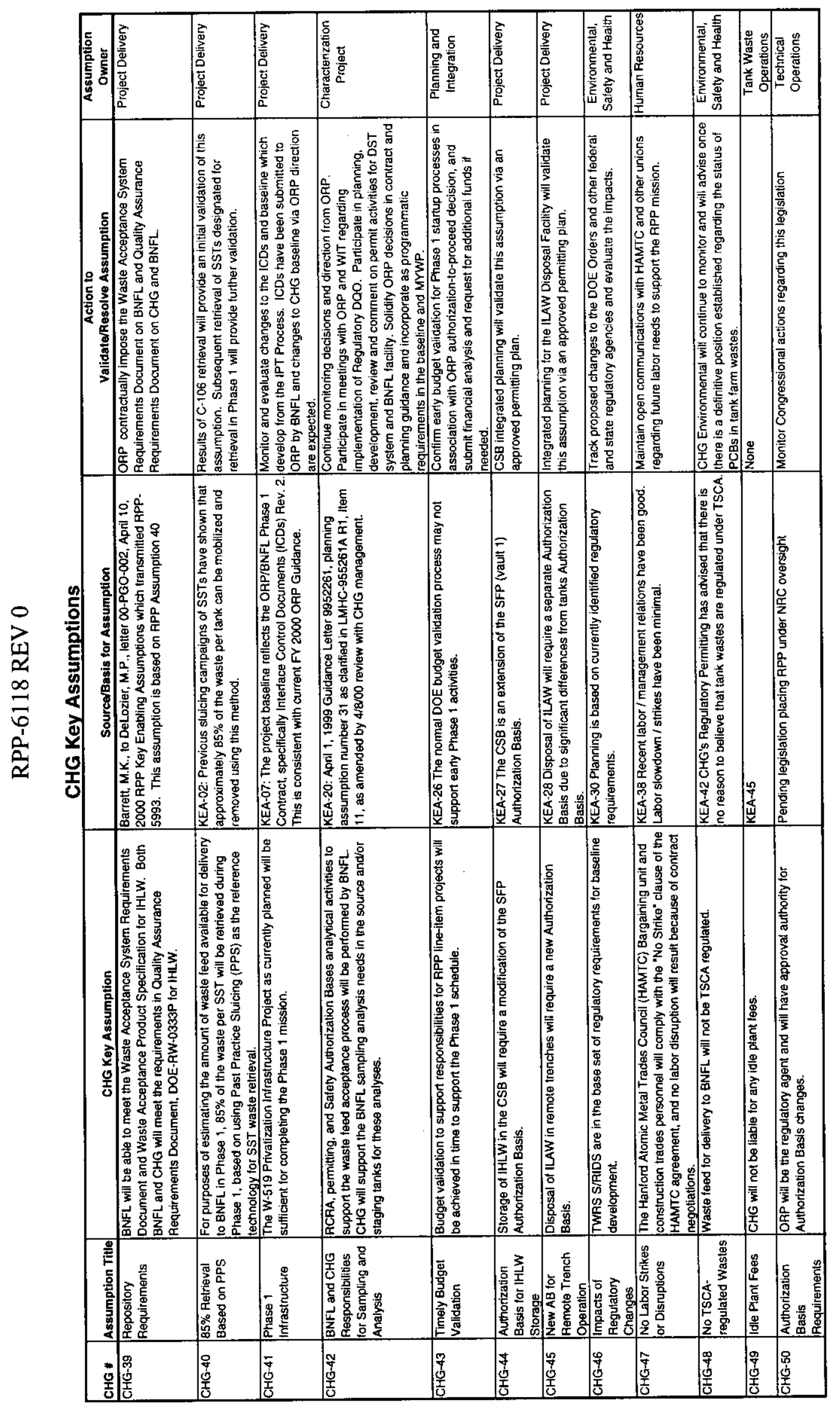


RPP-6118 REV 0

This page intentionally left blank. 
RPP-6118 REV 0

\section{APPENDIX B}

CH2M HILL HANFORD GROUP, INC. CRITICAL RISKS 
RPP-6118 REV 0

This page intentionally left blank.

B-ii 


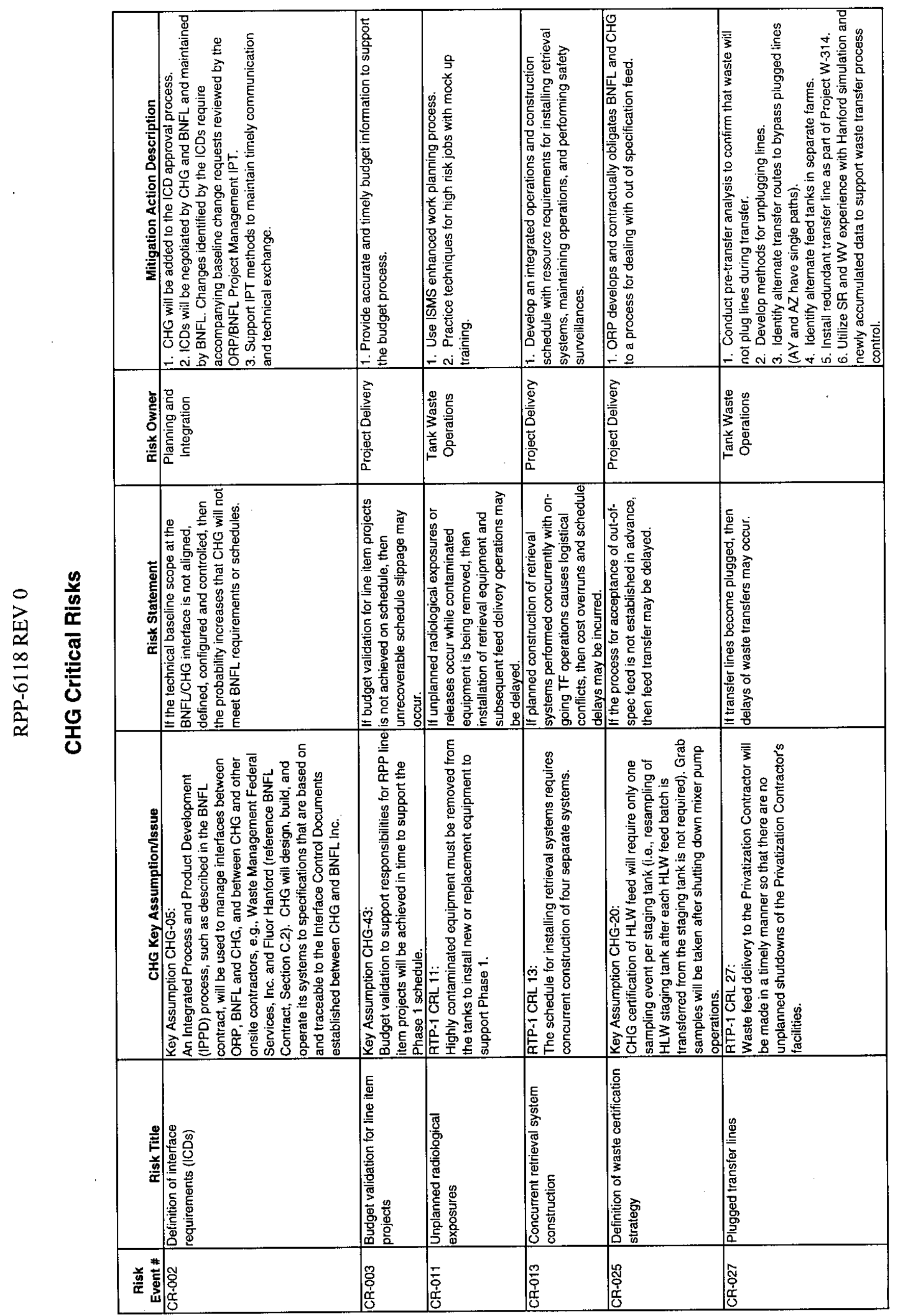




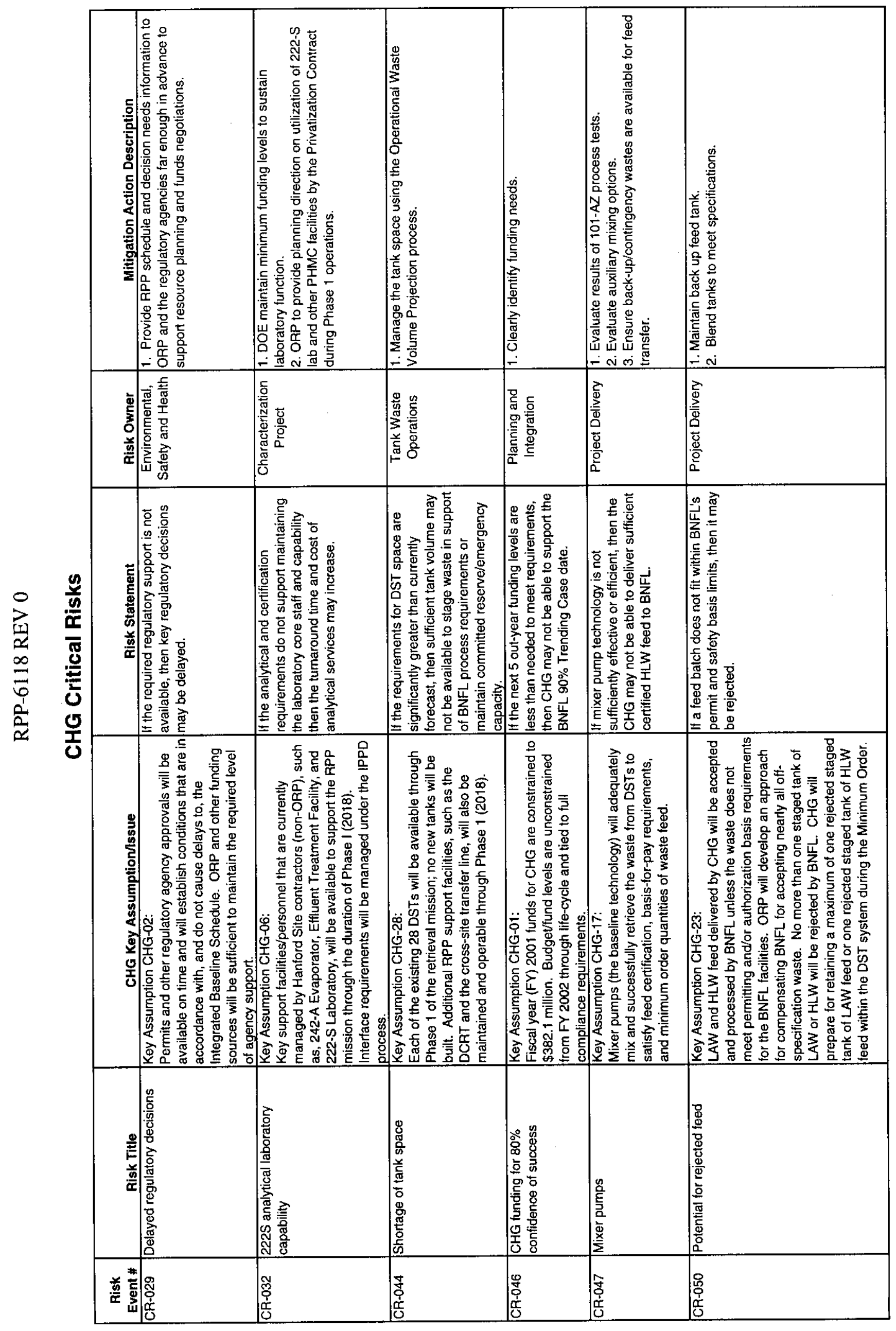




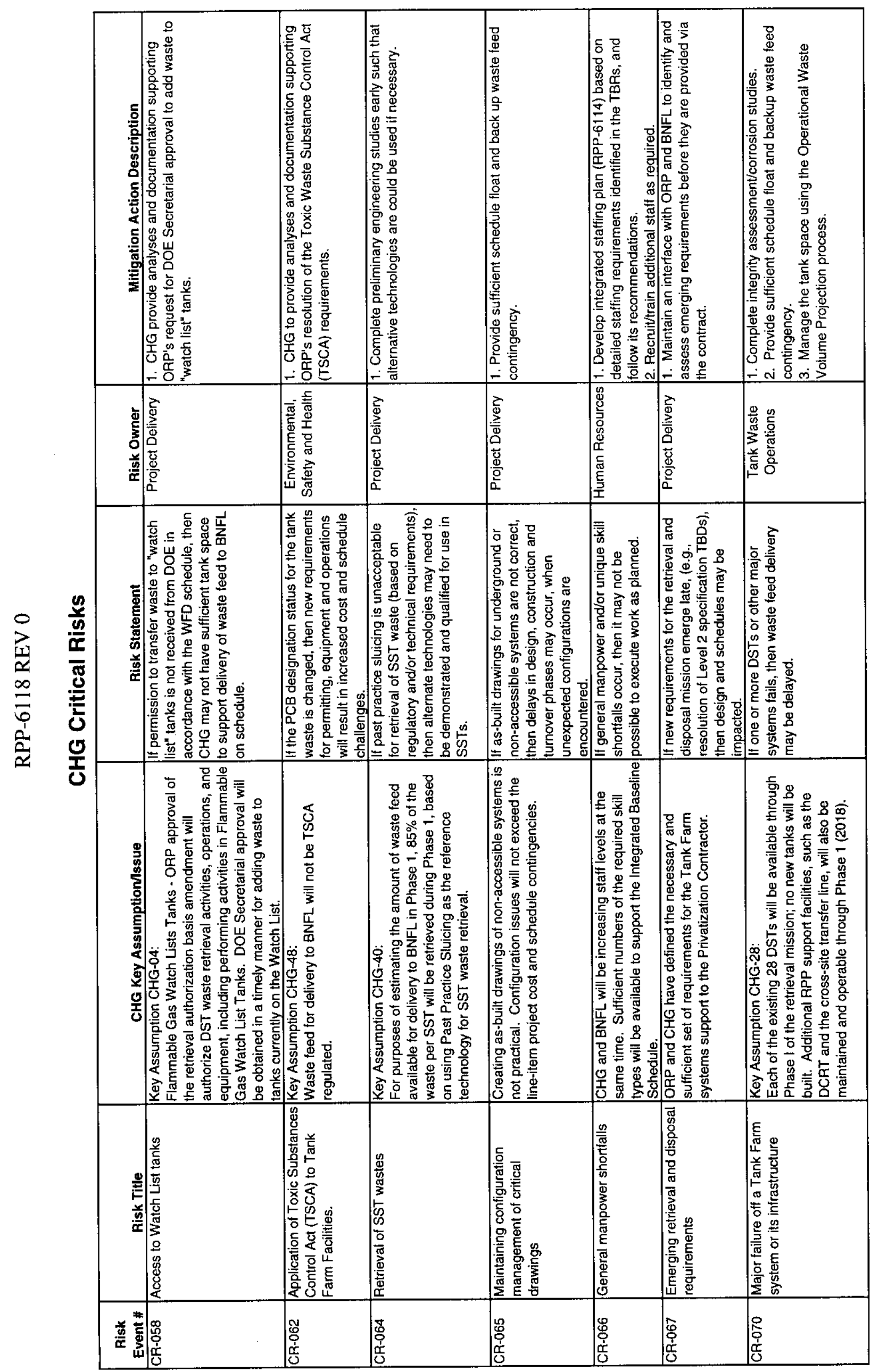




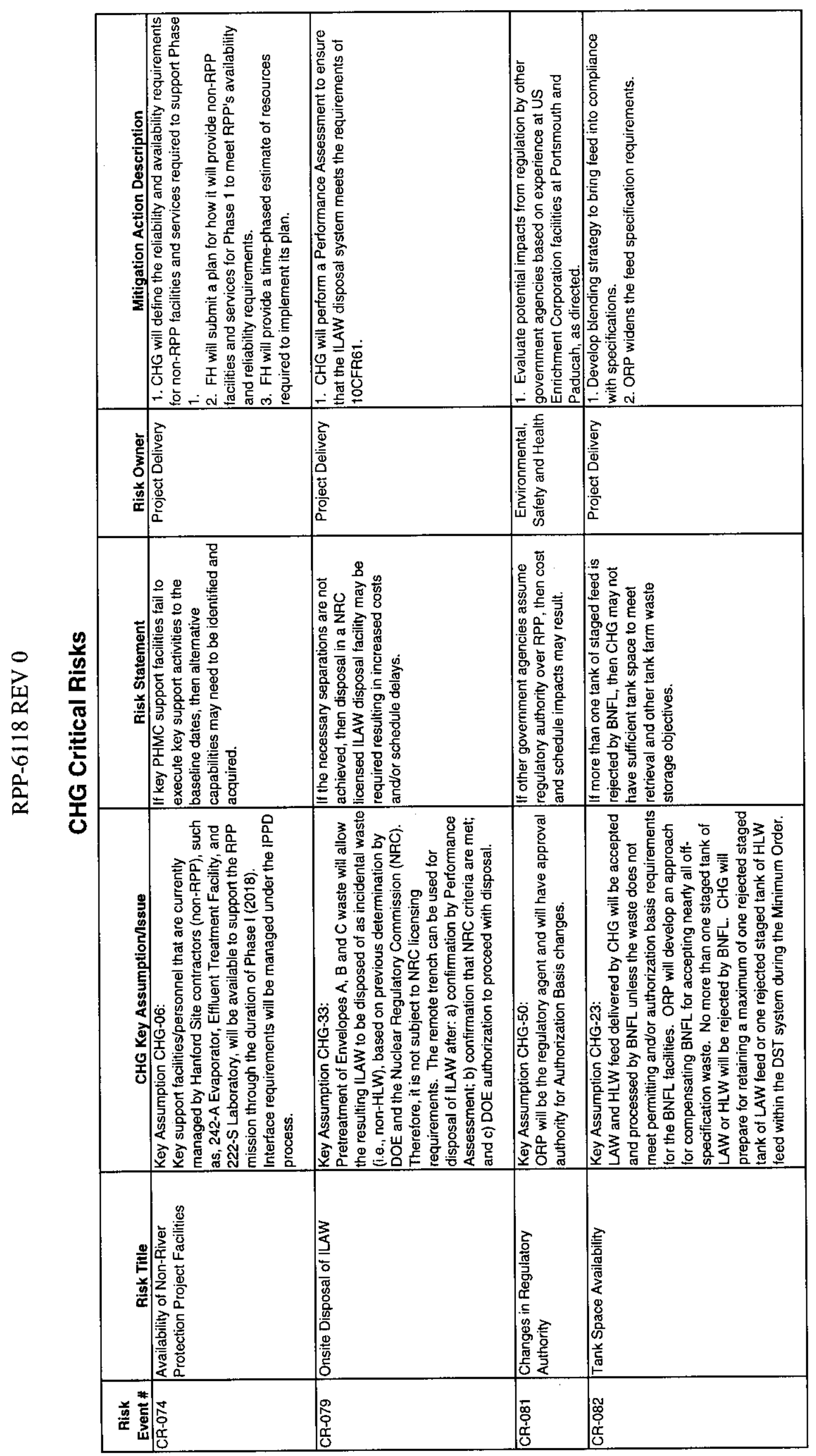


RPP-6118 REV 0

APPENDIX C

KEY FINDINGS 
RPP-6118 REV 0

This page intentionally left blank.

C-ii 


\section{RPP-6118 REV 0}

\section{APPENDIX C}

\section{KEY FINDINGS}

The TFC Operation and Utilization Plan (TFC O\&UP) describes the technical results from evaluating different scenarios for retrieving waste from the double-shell tanks (DSTs) and singleshell tanks (SSTs), staging, delivering, treating, immobilizing, storing, and disposing of the tank waste, and possible impacts for accomplishing the RPP mission. It is based upon the PIO guidance received from ORP in early April.

Key findings from the TFC O\&UP are:

- Contingency in Feed Delivery - A number of guidance features (Barrett 2000) and assumptions ensure that project upgrades are in place in advance of feed delivery actions. In addition, the staging strategy has been modified so that feeds are available from multiple sources in the event a failure occurs in a tank or a tank farm. This contingency provides good assurance that feed delivery will not result in an idle waste treatment processing facility.

- Flowsheet Variables - The quantity of glass produced (and the processing schedule) are influenced by uncertainties in waste inventory characterization, retrieval efficiencies, blending strategies, HLW solids wash/leach factors, and key glass-loading concentrations. Sensitivity cases have been run to bracket these variables such that where uncertainties exist, the impacts are understood (i.e. cases with and without sulfate removal have different, but predictable, glass volumes). Glass quantities and schedules are generally reliable for Phase 1.

- Meeting LAW and HLW Feed Specifications - The current tank sequence may not comply with the envelope specifications for every tank. These issues appear to be manageable and can probably be resolved by expanding the specification limits to fit the waste feeds after the processing impacts are reviewed.

- Risk Based Retrieval Sequence - SST retrieval is prioritized in 10 categories to retrieve tanks that: 1) have the greatest environmental hazard (high ${ }^{99} \mathrm{Tc}$ ), and 2) least complicated to retrieve (leaking tanks last). The sequence is optimized to keep LAW and HLW feed balanced to avoid processing shutdowns and to enhance incidental blending that occurs during retrieval.

- Number of Simultaneous Retrievals - Case $3 \mathrm{~S} 6 \mathrm{E}$ is based on a Phase 2 processing rate that enables completion of the mission by 2032 . The modeling assumes seven simultaneous retrieval machines are available for operation (RTP 1 assumed a maximum of 5). This assumption is used for all cases. Retrieval does not constrain processing in any case. The risk based retrieval sequence does add simultaneous retrievals per tank farm. 


\section{RPP-6118 REV 0}

- Product Returns - Case 3S6E assumes (per PIO 2000) no return streams from BNFL, Inc. and existing spare space in the DST's would cover a tank failure. This guidance relieves peak tank space concerns just prior to feed delivery and must be preserved. The routings to make transfers back to the tank farms are still intact.

Several alternatives were evaluated in the period leading up to the Readiness To Proceed 2 activity. Generally, these evaluations were conducted as part of the Integrated Product and Process Development approach together with DOE, BNFL, and the other Hanford Site contractors.

\section{Scenarios Supporting TFC O\&UP}

More than a dozen alternatives were modeled using the HTWOS model for the latest revision of the TFC O\&UP. These were variations of three general scenarios:

- Changes in start-up schedules for the RPP Waste Treatment Plant

- Changes.in the rate at which the RPP Waste Treatment Plan facilities are able to achieve their maximum sustainable operating rate.

- Changes in waste loading in the immobilized glass products.

The TFC O\&UP details the alternative cases, input parameters, and associated results.

The 3S6D scenario was prepared to model the FY 2000 Tank Farm Contractor guidance from $\mathrm{DOE}$. More recently, the $3 \mathrm{~S} 6 \mathrm{E}$ scenario was prepared to approximate the guidance from the DOE as contained in the PIO Key Enabling Assumptions (Barrett 2000). Table 1 shows a comparison of the 3S6D and 356E and Construction Project Baseline Guidance and Results.

The 3S6D scenario was prepared to model the FY 2000 Tank Farm Contractor guidance from DOE. More recently, the 3S6E scenario was prepared to approximate the guidance from the DOE as contained in the PIO Key Enabling Assumptions (Barrett 2000). Table 1 shows a comparison of the 3S6D and 3S6E and Construction Project Baseline Guidance and Results.

The initial start-up dates are the same for both the 3S6D and 3S6E cases. The key differences lie in the amount of waste loading in the ILAW, the melter ramp up rate, the ILAW produced, and the ramp up of LAW feed delivered to BNFL. In case 3S6D, BNFL removes sulfate and so the sodium loading for Envelope B, the sulfate containing waste, has a high waste loading (19.5\%). As a result, fewer canisters of glass are produced (12500). In case 3S6E BNFL does not remove sulfate and so the sodium loading for envelope B has a low waste loading (7.5\%). As a result for the same ramp up of LAW feed delivered to BNFL as case 3S6D, the number of canisters of glass is higher than the 3 S6D case (13500). The Proposed RTP Project Baseline has the same high waste loading $(19.5 \%)$ as case $3 \mathrm{~S} 6 \mathrm{D}$. However, the TFC has planned to deliver feed at a faster ramp up rate than the two previous cases. Therefore even with the higher waste loading, BNFL produces more canisters of glass (almost as many as with the low waste oxide loading of 3S6E (13366 versus 13500). To do this, BNFL must have a significantly higher melter ramp up rate. This means that the TFC Proposed RTP Project Baseline for LAW feed is able to accommodate the case $3 \mathrm{~S} 6 \mathrm{E}$ corresponding to a significantly higher BNFL melter ramp-up rate. 
Table 1. Comparison of 3S6D and 3S6E Guidance and Results - Phase 1.

\begin{tabular}{|c|c|c|}
\hline \multicolumn{3}{|c|}{ Phase 1 Guidance } \\
\hline Cases & $\begin{array}{l}\text { FY2000 Contract Guidance }{ }^{1,2,3} \\
\text { (Case 3S6D) }\end{array}$ & $\begin{array}{c}\text { April PIO Planning Guidance } \\
\text { (Case 3S6E) }\end{array}$ \\
\hline Key Differences & $\begin{array}{l}\text { 1) Sulfate Removal and } \\
\text { 2) } 1 \text { times the BNFL Integrated } \\
\text { Master Plan Ramp-up Rate for } \\
\text { LAW }\end{array}$ & $\begin{array}{l}\text { 1) No Sulfate Removal and } \\
\text { 2) } 2 \text { times the BNFL Integrated } \\
\text { Master Plan Ramp-up Rates for } \\
\text { LAW }\end{array}$ \\
\hline \multicolumn{3}{|c|}{ Low-Activity Waste } \\
\hline Initiate PT Hot Start & $4 / 30 / 06$ & $4 / 30 / 06$ \\
\hline First LAW Delivery AP-101 & $4 / 30 / 06$ & $4,4 / 30 / 06$ \\
\hline Initiate LAW Hot Start & $11 / 30 / 06$ & $1 / 30 / 06$ \\
\hline Initiate LAW Vit. Services & $3 / 1 / 08$ & $+4=3 / 1 / 08$ \\
\hline $\begin{array}{l}\text { LAW Treatment Ramp Up } \\
\text {-Nominal rate }=754 \text { units/yr } \\
\text {-2.38 ILAW. packages/day }\end{array}$ & \begin{tabular}{cr} 
From - To & \multicolumn{1}{c}{ Units/Yr } \\
$11 / 30 / 06-11 / 30 / 07$ & $151(20 \%)$ \\
$11 / 30 / 07-11 / 30 / 08$ & $452(60 \%)$ \\
$11 / 30 / 08-11 / 30 / 09$ & $754(100 \%)$ \\
Through Ext. Order & $1100(146 \%)$
\end{tabular} & $\begin{array}{l}\begin{array}{c}\text { From } \\
11 / 30 / 06\end{array}-11 / 30 / 07 \quad 279(37 \%) \\
11 / 30 / 07-11 / 30 / 08,830(110 \%) \\
11 / 30 / 08-11 / 30 / 09,1011(134 \%) \\
\text { Through Ext Order } 1100(146 \%)\end{array}$ \\
\hline $\begin{array}{l}\text { BNFL Sulfate Removal } \\
-\mathrm{Na}_{2} \mathrm{O} \text { Loading in Envelope B }\end{array}$ & $\begin{array}{c}\text { Yes } \\
19.5 \text { wt.\% }\end{array}$ & 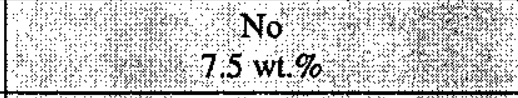 \\
\hline $\begin{array}{l}\text { Product Return Starts When } \\
\text { BNFL Lag Storage is X\% Full }\end{array}$ & $\begin{array}{c}\text { (ILAW/IHLW) } \\
50 \% / 50 \%{ }^{5}\end{array}$ & $\begin{array}{l}\text { (LAW/THLW) } \\
50 \% / 50 \%\end{array}$ \\
\hline \multicolumn{3}{|c|}{ High-Level Waste } \\
\hline First HLW Delivery AZ-101 & $10 / 31 / 06$ & NHW \\
\hline Initiate HLW Hot Start & $5 / 31 / 07$ & W \\
\hline Initiate HLW Vit. Services & $9 / 1 / 08$ & W \\
\hline $\begin{array}{l}\text { HLW Treatment Ramp Up } \\
\text {-Nominal rate }=102 \text { cans } / \mathrm{yr} \\
-0.28 \text { IHLW canisters } / \text { day }\end{array}$ & \begin{tabular}{|lr} 
From - To & \# Canisters \\
$9 / 1 / 08-8 / 31 / 09$ & $41(40 \%)$ \\
Through Ext. Order & $120(117 \%)$ \\
\end{tabular} & $\begin{array}{l}\text { From - To, } \\
971708-8 / 31 / 09 \\
\text { Through Ext. Order } \quad 41(40 \%) \\
120(17 \%)\end{array}$ \\
\hline HLW Waste Oxide Loading & Glass Properties Model Calc. & Glass Properties Model Calc, \\
\hline \multicolumn{3}{|c|}{ Phase 1 Projections Through the BNFL Inc. Contract Period (2/28/18) } \\
\hline \#ILAW Packages & 12,500 & Why \\
\hline \#IHLW Packages & 1,060 & 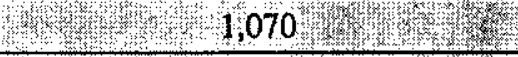 \\
\hline $\begin{array}{l}\text { Date When BNFL Lag } \\
\text { Product Storage is 50\% Full }\end{array}$ & $\begin{array}{l}\text { ILAW - January } 2008 \\
\text { IHLW - April } 2009\end{array}$ & $\begin{array}{l}\text { ILAW - August 2007 } \\
\text { IHLW - April 2009, }\end{array}$ \\
\hline LAW Feed Delivery Dates & \multicolumn{2}{|c|}{ All tanks are staged for delivery on the same dates for both cases } \\
\hline HLW Feed Delivery Dates & \multicolumn{2}{|c|}{ All tanks are staged for delivery on the same dates for both cases } \\
\hline $\begin{array}{l}{ }^{1} \text { Multi-Year Work Plan Upd } \\
{ }^{2} \text { Lockheed Martin Hanford C } \\
{ }^{3} \text { Mission Planning Guidance } \\
{ }^{4} \text { Project Integration Office A } \\
{ }^{5} \text { Appendix A Modeling Assu }\end{array}$ & $\begin{array}{l}\text { uidance for FY2000 (DOE-OR } \\
\text { ration Work Authorization for } \\
\text { Y } 2002 \text { (DOE-ORP 2000) } \\
000 \text { Guidance (PIO 2000) }\end{array}$ & E-ORP 1999) \\
\hline
\end{tabular}


Table 1. Comparison of 3S6D and 3S6E Guidance and Results - Phase 2.

\begin{tabular}{|c|c|c|}
\hline \multicolumn{3}{|c|}{ Phase 2 Guidance } \\
\hline Cases & $\begin{array}{l}\text { FY2000 Contract Guidance } \\
\text { (Case 3S6D) }\end{array}$ & $\begin{array}{c}\text { Apri plo planning Gudanee } \\
\text { (Case 3S6E) }\end{array}$ \\
\hline Key Differences & 2X/4X LAW/HLW Phase 2 Rates & $4 \times 8 \times 1 \mathrm{~A}$ WILW Phase 2 Rates \\
\hline Vitrification Rates & 2X LAW/4X HLW Phase 1 rates & $4 X L A W / 8 X+1 \mathrm{~W}$ Phase 1 rates \\
\hline $\mathrm{Na}_{2} \mathrm{O}$ Loading in ILAW & $20 \mathrm{wt} . \%$ & 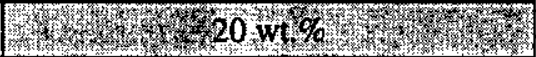 \\
\hline \multicolumn{3}{|c|}{ Phase 2 Projections } \\
\hline LAW Completion & March 2042 & 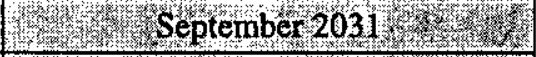 \\
\hline HLW Completion & April 2043 & W 1 May 2032, \\
\hline $\begin{array}{l}\text { Total ILAW Production } \\
\text { (\# ILAW Packages) }\end{array}$ & 63,200 & 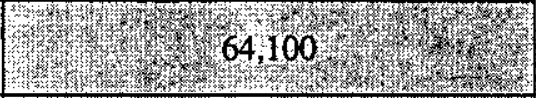 \\
\hline $\begin{array}{l}\text { Total IHLW Production } \\
\text { (\# IHLW Canisters) }\end{array}$ & 12,600 & (3) \\
\hline
\end{tabular}

In comparing the three cases for HLW, no significant differences exist from a feed standpoint. Thus, the comparison shows that the TFC Proposed RTP Project Baseline for HLW Feed is able to accommodate the case 3S6E. Furthermore, the total amount of IHLW canisters for Phase 1 for Case 3S6E (1070 canisters) can be accommodated by the TFC Proposed RTP Project Baseline (1120 canisters)

The TFC Proposed RTP Project Baseline for ILAW Disposal Facility attains critical decision 4 in June 2007. At this point TFC has completed their operational readiness review and is ready to receive waste from BNFL. In the PIO guidance of April upon which case $3 \mathrm{~S} 6 \mathrm{E}$ is based TFC received different constraints of the date at which ILAW canisters shipments from BNFL would be started. One constraint of the guidance stated that TFC would need to begin receiving shipment when BNFL storage capacity reached 50\%. This date was calculated to be August 2007. Another constraint that PIO provided in their guidance was that the date should be December 2007. Either of these dates can be accommodated by the TFC Proposed Baseline.

The TFC Proposed RTP Project Baseline for IHLW attains critical decision 4 in June 2008 and thus is ready to receive IHLW' canisters from BNFL. Again similar multiple constraints were provided in PIO guidance. For the $50 \%$ of storage capacity case, TFC needs to begin receiving IHLW in April 2009. PIO guidance also provided the constraint that the shipments would begin in September 2009. Either of these dates can be accommodated by the TFC Proposed Baseline.

Table 2 demonstrates that the case $3 \mathrm{~S} 6 \mathrm{E}$ is compliant with the Privatization contract from the standpoint of the total amount of LAW units of feed delivered to the Privatization Contractor. The minimum order quantity of LAW (6000 units) is completed during the processing of SY-101 in 2012. Extended order quantities of LAW are also provided in the table. 
Table 2. Low-Activity Waste.

\begin{tabular}{|c|c|c|c|c|c|}
\hline \multicolumn{5}{|c|}{ PIO Guidance } & \multicolumn{2}{c|}{ Results } \\
\hline $\begin{array}{c}\text { Delivery } \\
\text { sequence }\end{array}$ & $\begin{array}{c}\text { Source } \\
\text { tank }\end{array}$ & $\begin{array}{c}\text { Expected } \\
\text { envelope }\end{array}$ & $\begin{array}{c}\text { Estimated delivered } \\
\text { quantity (units) }\end{array}$ & $\begin{array}{c}\text { Modeled units } \\
\text { delivered }\end{array}$ & $\begin{array}{c}\text { Modeled delivery } \\
\text { date }\end{array}$ \\
\hline 1 & AP-101 & A & 615 & 615 & $04 / 29 / 06$ \\
\hline 2 & AZ-101 & B & 869 & 866 & $07 / 08 / 07$ \\
\hline 3 & AZ-102 & B & 447 & 445 & $03 / 29 / 08$ \\
\hline 4 & AN-102 & C & 1112 & 1112 & $04 / 10 / 08$ \\
\hline 5 & AN-104 & A & 845 & 845 & $09 / 29 / 10$ \\
\hline 6 & AN-107 & C & 808 & 808 & $07 / 08 / 11$ \\
\hline 7 & AN-105 & A & 839 & 839 & $04 / 01 / 12$ \\
\hline $8^{\mathrm{a}}$ & SY-101 & A & 826 & 827 & $01 / 16 / 13$ \\
\hline 9 & AN-103 & A & 1084 & 1084 & $10 / 08 / 13$ \\
\hline 10 & AW-101 & A & 1070 & 1070 & $10 / 04 / 14$ \\
\hline
\end{tabular}

LAW $=$ Low-activity Waste

$\mathrm{PIO}=$ Project Integration Office

${ }^{a}$ Minimum delivery order of 6000 units is reached during processing SY-101 waste. The subsequent tanks provide contingency waste feed.

Table 3 demonstrates that the case $3 \mathrm{~S} 6 \mathrm{E}$ is compliant with the Privatization contract from the standpoint of total amount of HLW delivered to the Privatization Contractor. The minimum order quantity for HLW (equivalent to 600 canisters of IHLW) is completed during the processing of C-104 and AY-101 in 2012. Extended order quantities of HLW are also provided in the table.

Table 3. High-Level Waste.

\begin{tabular}{|c|c|c|c|c|c|}
\hline \multicolumn{5}{|c|}{ PIO Guidance } & \multicolumn{2}{c|}{ Results } \\
\hline $\begin{array}{c}\text { Delivery } \\
\text { sequence }\end{array}$ & $\begin{array}{c}\text { Source } \\
\text { tank }^{\text {(a) }}\end{array}$ & $\begin{array}{c}\text { Expected } \\
\text { envelope }\end{array}$ & $\begin{array}{c}\text { Estimated delivered } \\
\text { quantity (canisters) }\end{array}$ & $\begin{array}{c}\text { Modeled delivery } \\
\text { quantity (canisters) }\end{array}$ & $\begin{array}{c}\text { Modeled } \\
\text { delivery date }\end{array}$ \\
\hline 1 & AZ-101 & D & 81 & 81 & $09 / 01 / 05$ \\
\hline 2 & AZ-102 & D & 123 & 123 & $02 / 01 / 08$ \\
\hline 3 & AY-102 & D & 191 & 191 & $10 / 01 / 10$ \\
\hline $4^{(c)}$ & $\begin{array}{c}\text { C-104 and } \\
\text { AY-101 }\end{array}$ & D & 343 & 343 & $06 / 01 / 12$ \\
\hline 5 & SY-102 & D & 226 & 227 & $04 / 01 / 15$ \\
\hline
\end{tabular}

HLW $=$ High-level waste

$\mathrm{PIO}=$ Project Integration Office

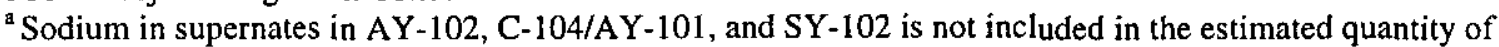
low-activity waste (LAW).

${ }^{b}$ Includes impacts of strontium and manganese additions for pretreating Envelope $\mathrm{C}$ waste, use of the Pacific Northwest National Laboratory (PNNL) Glass Properties Model, and results of sludge washing testing for predicting waste loading in glass.

${ }^{c}$ The minimum delivery order of 600 canisters is reached during processing C-104/AY-101 waste. The subsequent tank provides contingency waste feed. 


\section{RPP-6118 REV 0}

This page intentionally left blank.

C-6 